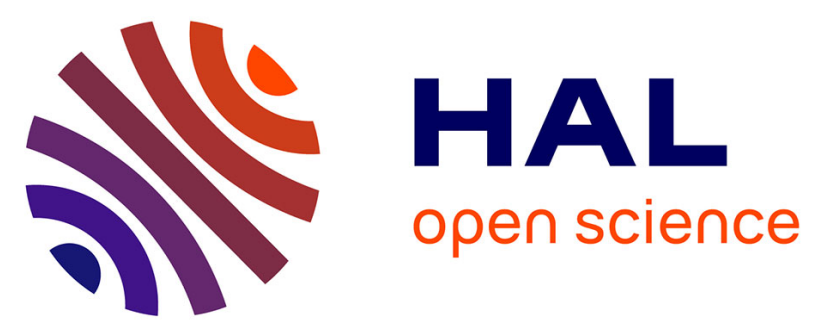

\title{
The primary volcanic aerosol emission from Mt Etna: size-resolved particles with SO 2 and role in plume reactive halogen chemistry
}

Tjarda J. Roberts, D. Vignelles, M. Liuzzo, G. Giudice, A. Aiuppa, M. Coltelli, G. Salerno, Michel Chartier, Benoît Couté, Gwenaël Berthet, et al.

\section{To cite this version:}

Tjarda J. Roberts, D. Vignelles, M. Liuzzo, G. Giudice, A. Aiuppa, et al.. The primary volcanic aerosol emission from Mt Etna: size-resolved particles with SO 2 and role in plume reactive halogen chemistry. Geochimica et Cosmochimica Acta, 2018, 222, pp.74-93. 10.1016/j.gca.2017.09.040 . insu-01618121

\section{HAL Id: insu-01618121 https://hal-insu.archives-ouvertes.fr/insu-01618121}

Submitted on 17 Oct 2017

HAL is a multi-disciplinary open access archive for the deposit and dissemination of scientific research documents, whether they are published or not. The documents may come from teaching and research institutions in France or abroad, or from public or private research centers.
L'archive ouverte pluridisciplinaire HAL, est destinée au dépôt et à la diffusion de documents scientifiques de niveau recherche, publiés ou non, émanant des établissements d'enseignement et de recherche français ou étrangers, des laboratoires publics ou privés. 


\section{Accepted Manuscript}

The primary volcanic aerosol emission from Mt Etna: size-resolved particles with $\mathrm{SO}_{2}$ and role in plume reactive halogen chemistry

T.J. Roberts, D. Vignelles, M. Liuzzo, G. Giudice, A. Aiuppa, M. Coltelli, G. Salerno, M. Chartier, B. Couté, G. Berthet, T. Lurton, F. Dulac, J.-B. Renard

PII: S0016-7037(17)30629-4

DOI: https://doi.org/10.1016/j.gca.2017.09.040

Reference: GCA 10492

To appear in:

$$
\text { Geochimica et Cosmochimica Acta }
$$

Received Date: $\quad 13$ September 2016

Accepted Date: $\quad 23$ September 2017

Please cite this article as: Roberts, T.J., Vignelles, D., Liuzzo, M., Giudice, G., Aiuppa, A., Coltelli, M., Salerno, G., Chartier, M., Couté, B., Berthet, G., Lurton, T., Dulac, F., Renard, J.-B., The primary volcanic aerosol emission from Mt Etna: size-resolved particles with $\mathrm{SO}_{2}$ and role in plume reactive halogen chemistry, Geochimica et Cosmochimica Acta (2017), doi: https://doi.org/10.1016/j.gca.2017.09.040

This is a PDF file of an unedited manuscript that has been accepted for publication. As a service to our customers we are providing this early version of the manuscript. The manuscript will undergo copyediting, typesetting, and review of the resulting proof before it is published in its final form. Please note that during the production process errors may be discovered which could affect the content, and all legal disclaimers that apply to the journal pertain. 


\title{
The primary volcanic aerosol emission from Mt Etna: size-resolved particles with $\mathrm{SO}_{2}$ and role in plume reactive halogen chemistry
}

T.J. Roberts ${ }^{a}$, D. Vignelles ${ }^{a}$, M. Liuzzo ${ }^{b}$, G. Giudice $^{b}$, A. Aiuppa $^{c}$, M. Coltelli ${ }^{d}$, G. Salerno ${ }^{d}$, M. Chartier ${ }^{a}$, B. Couté ${ }^{\mathrm{a}}, \mathrm{G}$. Berthet ${ }^{\mathrm{a}}$, T. Lurton ${ }^{\mathrm{a}}$, F. Dulac ${ }^{\mathrm{e}}$, J.-B. Renard ${ }^{\mathrm{a}}$

aLPC2E-CNRS/Université d'Orléans, 3A avenue de la recherche scientifique, 45071 Orléans, France

IIstituto Nazionale di Geofisica e Vulcanologia, sezione di Palermo, Via La Malfa 153, 90146 Palermo, Italy

'Dipartimento DiSTeM, Università di Palermo, Via Archirafi 36, 90123 Palermo, and Istituto Nazionale di Geofisica e Vulcanologia, sezione di Palermo, Via La Malfa 153, 90146 Palermo, Italy

dIstituto Nazionale di Geofisica e Vulcanologia, Osservatorio Etneo, Piazza Roma 2, Catania 95125, Italy

eLSCE-IPSL, CEA-CNRS-UVSQ, Université Paris-Saclay, CEA Saclay 701, 91191 Gif-sur-Yvette, France

"Corresponding author, Tjarda.Roberts@cnrs-orleans.fr

\begin{abstract}
Volcanoes are an important source of aerosols to the troposphere. Within minutes after emission, volcanic plume aerosol catalyses conversion of co-emitted $\mathrm{HBr}, \mathrm{HCl}$ into highly reactive halogens (e.g. $\mathrm{BrO}, \mathrm{OClO}$ ) through chemical cycles that cause substantial ozone depletion in the dispersing downwind plume.

This study quantifies the sub-to-supramicron primary volcanic aerosol emission (0.2-5 $\mu \mathrm{m}$ diameter) and its role in this process. An in-situ ground-based study at Mt Etna (Italy) during passive degassing co-deployed an optical particle counter and Multi-Gas $\mathrm{SO}_{2}$ sensors at high time resolution $(0.1 \mathrm{~Hz})$ enabling to characterize the aerosol number, size-distribution and emission flux.
\end{abstract}

A tri-modal volcanic aerosol size distribution was found, to which lognormal distributions are fitted. Total particle volume correlates to $\mathrm{SO}_{2}$ (as a plume tracer). The measured particle volume: $\mathrm{SO}_{2}$ ratio equates to a sulfate: $\mathrm{SO}_{2}$ ratio of $1-2 \%$ at the observed meteorological conditions (40\% Relative Humidity). A particle mass flux of $0.7 \mathrm{~kg} \mathrm{~s}^{-1}$ is calculated for the measured Mt Etna $\mathrm{SO}_{2}$ flux of 1950 tonnes/day.

A numerical plume atmospheric chemistry model is used to simulate the role of the hygroscopic primary aerosol surface area and its humidity dependence on volcanic plume $\mathrm{BrO}$ and $\mathrm{OClO}$ chemistry. As well as predicting volcanic $\mathrm{BrO}$ formation and $\mathrm{O}_{3}$ depletion, the model achieves $\mathrm{OClO} / \mathrm{SO}_{2}$ in broad quantitative agreement with recently reported Mt Etna observations, with a predicted maximum a few minutes downwind. In addition to humidity - that enhances aerosols surface area for halogen cycling - background ozone is predicted to be an important control on 
$\mathrm{OClO} / \mathrm{SO}_{2}$. Dependence of $\mathrm{BrO} / \mathrm{SO}_{2}$ on ambient humidity is rather low near-to-source but increases further downwind. The model plume chemistry also exhibits strong across-plume spatial variations between plume edge and centre.

\section{Keywords}

Particle, sulphate, halogen, impacts, volcano, atmospheric chemistry, troposphere, emission

\section{Highlights}

- In-situ small sensor quantification of Mt Etna primary aerosol emission

- Lognormal parameter fit finds trimodal primary aerosol, effective radius of $0.3 \mu \mathrm{m}$

- Data analysis of real-time observations extracts molar sulfate/ $/ \mathrm{SO}_{2}$ of $1-2 \%$

- Atmospheric model predicts OCIO consistent with reported Mt Etna plume observations

- Aerosol surface area-humidity dependence of young plume BrO-OCIO chemistry predicted

\section{Introduction}

Volcanoes release a complex and highly reactive cocktail of gases and aerosol to the atmosphere. Quiescent (passive) degassing contributes about $\sim 40 \%$ of volcanic emissions, to the troposphere, whilst the remaining $\sim 60 \%$ occurs by explosive eruptions to the troposphere or stratosphere (Halmer et al., 2002). This study focuses on the aerosol emissions and plume chemistry of Mt Etna (Italy) plume during continuous passive degassing.

Volcanic aerosols entering the troposphere impact climate through their effects on the earth's radiative balance (Schmidt et al., 2012, Ebmeier et al. 2014), are detrimental to the environment and health (Bussinger et al., 2015), and exert an important role in plume atmospheric chemistry: reactions on the acidic volcanic aerosol surface promote conversion of emitted volcanic halogens $(\mathrm{HBr}, \mathrm{HCl})$ into reactive halogens (e.g. BrO, OClO). Numerical models (MISTRA, PlumeChem) that simulate this plume chemistry predict depletion of tropospheric ozone (Bobrowski et al., 2007, Roberts et al., 2009, von Glasow et al., 2009), production of $\mathrm{HNO}_{3}$ (Roberts et al., 2009), and conversion of mercury into a more toxic and easily deposited form (von Glasow, 2010). To date, volcanic $\mathrm{BrO}$ but not $\mathrm{OClO}$ has been reproduced by simulations of plume gas-aerosol chemistry, albeit with models only partially constrained.

Aerosol surface area is a key control on the near-source plume chemistry (Roberts et al., 2009, von Glasow, 2010) and depends on both the flux and size distribution of the primary volcanic aerosol emission. Several studies (see Section 1.1) have contributed towards characterising the sulphate-rich aerosol emission during passive degassing. Aircraft have also sampled explosive ash-rich and aged plumes (e.g. Schumann et al., 2011 Carn et al., 2011). However, the surface area of the primary sulphate-rich aerosol remains a key uncertainty in atmospheric models of plume chemistry and its impacts (Roberts et al., 2014a, Jourdain et al., 2015). This study quantifies the sub-to-supramicron primary volcanic aerosol emission using real-time in-situ aerosol and $\mathrm{SO}_{2}$ sensors at quiescently 
degassing Mt Etna volcano, and uses a numerical model to evaluate the role of humidity and aerosol surface area on plume $\mathrm{BrO}$ and $\mathrm{OClO}$ chemistry.

\subsection{Volcanic aerosol observations}

Volcanoes are a source of both primary and secondary aerosol to the atmosphere. A review is given by Mather et al. (2004a). Here the focus is on ash-poor emissions. Evidence for a primary aerosol emission comes from filter-pack sampling at the volcanic crater-rim (Mather et al., 2003, Mather et al., 2006), which identifies aerosol ions including $\mathrm{SO}_{4}{ }^{2-}$, i.e. sulfate aerosol. This is also confirmed by real-time chemical sampling, Kroll et al. (2015).

Primary volcanic aerosol includes components either directly released or formed over secondsminutes timescale since release of the hot gas mixture from the vent. This contrasts with secondary sulfate aerosol that is formed by atmospheric oxidation of $\mathrm{SO}_{2}$ over typically hours to days. Thermodynamic models (e.g. Martin et al., 2006) indicate $\mathrm{H}_{2} \mathrm{SO}_{4}$-precursors (e.g. $\mathrm{SO}_{3}, \mathrm{OH}$ ) are formed at high-temperature near to the vent. These are a possible source of primary sulfate. However, this high-temperature region of the plume is difficult to observe in the field, and its representation using models has known caveats (e.g. Martin et al., 2009, Martin et al., 2012, Roberts et al., 2014a). Therefore the mechanisms are uncertain. Nevertheless, plume observations made at ambient temperature e.g. of $\mathrm{HO}_{2} \mathrm{NO}_{2}$ (a product of $\mathrm{HO}_{x}$ and $\mathrm{NO}_{\mathrm{x}}$ ) at $\mathrm{Mt}$ Erebus (Oppenheimer et al., 2010) do provide some evidence for high-temperature production of oxidised gas radicals. As the near-vent plume cools, reaction of $\mathrm{SO}_{3}$ with $\mathrm{H}_{2} \mathrm{O}$ (ubiquitous in the volcanic emission) could lead to a rapid production of gaseous $\mathrm{H}_{2} \mathrm{SO}_{4(\mathrm{~g})}$ that is highly hygroscopic and will therefore form aqueous $\mathrm{H}_{2} \mathrm{SO}_{4(\text { (aq) }}$ particles upon plume cooling. Particles might also be directly released. Ammann and Burtscher (1993) propose that nanometer-sized metal salts may seed sulfate particle formation, with subsequent growth by $\mathrm{H}_{2} \mathrm{SO}_{4}$ condensation and particle coagulation. Reaction of $\mathrm{H}_{2} \mathrm{SO}_{4}$ with metalchloride salts can partially neutralise the aerosol acidity, releasing metal ions such as $\mathrm{Na}^{+}{ }_{\text {(aq) }}$ (e.g. Martin et al., 2008) and $\mathrm{HCl}$ gas (Mather et al., 2004a). The result is a primary volcanic aerosol emission to the troposphere that is multi-modal in its size distribution (e.g. Allen et al., 2006). Sulfate is commonly a dominant component by mass but the aerosol emission can contain other ions (e.g. Quisefit et al., 1988; Toutain et al., 1995) or can atypically be halogen-rich, Ilyinskaya et al., (2010).

Volcanic aerosol can be characterised by (i) in-situ time-averaged sampling with laboratory analysis, (ii) remote sensing such as by sun-photometer and (iii) in-situ real-time sensing by optical particle counter (OPC). Previous aerosol studies at Mt Etna are listed in Table 1 (remote sensing) and Table 2 (in situ) and the three methods discussed below.

In-situ time-averaged sampling by filter-pack or cascade impactor (that separates the collected aerosol according to size) is reported by Vié le Sage (1983), Quisefit et al. (1988), Toutain et al. (1995), Allen et al. (2006) and Martin et al. (2008), finding high sulfur or sulfate content alongside other ions including metals, e.g. $\mathrm{Na}^{+}$. Allen et al. (2006) report that sulfate was mostly in coarse particles at North-east crater (NEC) but in fine particles at Voragine (VOR), confirmed by Martin et al. (2008) who report sulfate with either single or bi-modal distributions, centred at $\sim 1 \mu \mathrm{m}$ (at VOR and $\mathrm{NEC}$ ) and $\sim 8 \mu \mathrm{m}$ diameter (NEC only). Martin et al. (2008) report sulfate: $\mathrm{SO}_{2}$ molar ratios from summit filterpack sampling of $0.017-0.05$ and silica particles of $\sim 1 \mu \mathrm{m}$ with a flux of $\sim 7000 \mathrm{~kg} \mathrm{~d}^{-1}$. 
Sun-photometer remote sensing by Watson and Oppenheimer $(2000 ; 2001)$ quantified aerosol over 0.1-4 $\mu \mathrm{m}$ radius finding at least two size modes, an effective radius $\left(R_{\text {eff }}\right)$ of $\sim 0.7-0.85 \mu \mathrm{m}$ and some evidence for particle growth downwind. However, surface area and volume were constrained only as lower limits as the distribution maxima lie beyond the retrieval range. A lower limit for the particle mass flux was given as 4.5-8 $\mathrm{kg} \mathrm{s}^{-1}$. An airborne multispectral (visible + infra-red) imaging study by Spinetti and Buongiorno, (2007), also indicated likely presence of multiple size modes, an effective radius of $\sim 1 \mu \mathrm{m}$, but reported shrinkage of average particle size downwind (perhaps a consequence of the instrument size-range combined with aerosol microphysics). Sellito et al. (2016) detected aged aerosol by sun-photometer hundreds of km downwind from Mt Etna following an eruption event, reporting a bi-modal distribution, suggested to be sulfate (fine mode) and ash (coarse). Analysis of explosive events from Mt Etna observed by the MISR (Multiangle Imaging SpectroRadiometer) satellite instrument have also identified larger ash particles with finer sulfate-water particles (Scollo et al., 2012). Other studies have identified volcanic ash from satellite data but are not discussed here.

From real-time OPC measurements of aerosol number distribution at Mt Etna, Allen et al. (2006) report a trimodal distribution, with distinct NEC and VOR composition. However, surface area and volume distributions were not analysed. In the first application of an OPC to Mt Etna, Allen et al. (2006) emphasize the future potential application of $\mathrm{OPC}^{\prime} \mathrm{s}$ alongside in-situ $\mathrm{SO}_{2}$ gas sensors to deliver aerosol: $\mathrm{SO}_{2}$ ratios, whose combination with $\mathrm{SO}_{2}$ flux measured by UV remote sensing techniques such as COSPEC and DOAS (Differential Optical Absorption Spectroscopy) (Platt and Stutz, 2008) would enable a more accurate calculation of aerosol emission flux. Co-measurement of $\mathrm{SO}_{2}$ would also enable the volcanic aerosol component to be distinguished from other sources e.g. dust. This approach is used here. We note that previous in-situ field-measurements of near-source $\mathrm{Mt}$ Etna aerosol alongside $\mathrm{SO}_{2}$ found the OPC suffered from non-quantitative counting, preventing an accurate measurement (Vance et al., 2010). Here we trace and minimise such errors. Finally, in-situ measurements of aerosol in plume $>6 \mathrm{~km}$ downwind from Mt Etna have recently also been made by aircraft, reporting $R_{\text {eff }}=0.75-1.2$ and porosity (aerosol with air-holes) at the observed low ambient temperature and humidity (Shcherbakov et al., 2016).

These studies collectively demonstrate a sulfate-rich primary volcanic aerosol emission from Mt Etna but exhibit differences that include: single, bi- or tri-modal distributions, supra- or sub-micron volumic maxima, growth or shrinkage downwind. These differences may reflect particular meteorological/volcanological conditions or measurement limitations. There remains a need to further characterise the primary aerosol emission, whose surface area exerts an important role in plume atmospheric chemistry.

\subsection{The importance of volcanic aerosol in driving plume $\mathrm{BrO}, \mathrm{OClO}$ chemistry}

Volcanic aerosol catalyses plume chemical reactions that convert volcanic emissions of $\mathrm{HBr}$ and $\mathrm{HCl}$ into reactive halogens (e.g. $\mathrm{BrO}, \mathrm{OClO}$ ). Impacts from this plume chemistry include substantial depletion of ozone, as both predicted by atmospheric models (Von Glasow, 2009, Roberts et al., 2014a, and references therein) and observed (Vance et al., 2010, Schumann et al., 2011, Kelly et al. 2013, Surl et al., 2015). Important features of the volcano plume reactive halogen chemistry are 
summarised in Figure 1. The chemistry occurs through autocatalytic cycles, the so-called "bromine explosion", involving gas-aerosol, gas-phase and photolytic reactions R1-R6, where $\mathrm{X}$ is a halogen $\mathrm{Br}$ or $\mathrm{Cl}$. In strong (highly concentrated) plumes, additional $\mathrm{Br}$-mediated ozone depletion is caused by the cycle between R4 and R7. The onset of the low-temperature tropospheric chemistry cycles in the downwind plume is 'kick-started' by high-temperature near-vent formation of radicals and sulfate aerosol precursors.

$$
\begin{aligned}
& \text { R1 } \mathrm{BrONO}_{2(g)}+\mathrm{H}_{2} \mathrm{O}_{(a q)} \stackrel{\text { aerosotsurface }}{\longrightarrow} \mathrm{HOBr}_{(g)}+\mathrm{HNO}_{3(a q, g)} \\
& \text { R2 } \mathrm{HOBr}_{(g)}+\mathrm{HX}_{(a q)} \stackrel{\text { aerosotsurface }}{\longrightarrow} \mathrm{Br} X_{(g)}+\mathrm{H}_{2} \mathrm{O}_{(a q)} \\
& \mathrm{R} 3 \mathrm{BrX}_{(g)} \stackrel{\text { sunlight }}{\longrightarrow} \mathrm{Br} r_{(g)}+X_{(g)} \\
& \text { R4 } \mathrm{Br}_{(g)}+\mathrm{O}_{3(g)} \rightarrow \mathrm{BrO}_{(g)}+\mathrm{O}_{2(g)} \\
& \text { R5 } \mathrm{BrO}_{(g)}+\mathrm{HO}_{2(g)} \rightarrow \mathrm{HOBr}_{(g)}+\mathrm{O}_{2(g)} \\
& \text { R6 } \mathrm{BrO}_{(g)}+\mathrm{NO}_{2(g)} \rightarrow \mathrm{BrONO} O_{2(g)} \\
& \text { R7 } \mathrm{BrO}_{(g)}+\mathrm{BrO}_{(g)} \rightarrow 2 \mathrm{Br}+\mathrm{O}_{2(g)}
\end{aligned}
$$$$
\mathrm{R} 2 \mathrm{HOBr}_{(g)}+\mathrm{HX}_{(a q)} \stackrel{\text { aerosotsurface }}{\longrightarrow} \mathrm{BrX}(\mathrm{g})+\mathrm{H}_{2} \mathrm{O}_{(a q)}
$$

Understanding $\mathrm{BrO}$ as a proxy for volcanic $\mathrm{HBr}$ emissions is a strong interest at Mt Etna, Italy, where $\mathrm{BrO}$ is frequently measured and $\mathrm{OClO}$ has also been observed (Bobrowski et al., 2007; Bobrowski and Guiffrida, 2012; General et al., 2014; Gliß et al., 2015). Unexpectedly, $\mathrm{BrO}_{\mathrm{SO}}$ at $\mathrm{Mt}$ Etna showed no observable dependence on relative humidity $(\mathrm{RH})$ despite expectations to the contrary given high $\mathrm{RH}$ should enhance the hygroscopic volcanic aerosol surface area, promoting R1, R2 (Bobrowski and Guiffrida, 2012). This issue is investigated through modelling in this study.

Critical to the bromine explosion cycle are the heterogeneous (gas-aerosol) reactions (R1, R2) on the acidic aerosol surface area. The product of aerosol-catalysed reaction $R 2$ is initially $\mathrm{Br}_{2}(\mathrm{X}=\mathrm{Br})$ for a typical volcanic emission composition such as at Mt Etna, see Roberts et al. (2014a). This leads to a rapid conversion of volcanic $\mathrm{HBr}$ into reactive bromine species including $\mathrm{BrO}$. As the plume $\mathrm{HBr}$ becomes depleted the $\mathrm{R} 2$ reaction can instead release $\mathrm{BrCl}$, that photolyses to generate $\mathrm{Br}$ and $\mathrm{Cl}$ radicals (R3), leading to formation of $\mathrm{ClO}$ and $\mathrm{OClO}$ by $\mathrm{R} 8-\mathrm{R} 9$.

$\mathrm{R} 8 \mathrm{Cl}_{(g)}+\mathrm{O}_{3(g)} \rightarrow \mathrm{ClO}_{(g)}+\mathrm{O}_{2(g)}$

$\mathrm{R9} \mathrm{ClO}_{(g)}+\mathrm{BrO}_{(g)} \rightarrow \mathrm{OClO}_{(g)}+\mathrm{Br}_{(g)}$

This proposed mechanism is of interest regarding OClO recently reported in Mt Etna plume (Bobrowski et al., 2007; General et al., 2015, Gliß et al., 2015). Volcanic OClO has also been reported in the tropospheric plume of Soufrière Hills (Donovan et al., 2014), and the stratospheric plume of Puyehue-Cordón Caulle (Theys et al., 2014). Observations of volcanic OClO have not been reproduced by atmospheric models to date, but are simulated here for Mt Etna using a box model (Section 4.2). Predicted impacts of the plume reactive chlorine chemistry include enhancing BrO- 
induced ozone depletion and mercury deposition, and shortening of the lifetime of key climate gas methane through reaction with $\mathrm{Cl}$ radicals (Gliß et al., 2015, Jourdain et al., 2016).

\section{Methods}

During our field-campaign, 2-4 October, 2013, Mt Etna was quiescently degassing from three summit craters: North East Crater (NEC), Voragine (VOR), Bocca Nuova (BNC), these last two also known as Central Craters (CC), with no visible evidence for ash in their plumes. The OPC aerosol and Multi-Gas instruments were deployed as close to each other as possible (typically $10^{\prime} \mathrm{s} \mathrm{cm}$ ) to facilitate direct in-situ comparison of the real-time (1-10's s) measurements. On 2 October, summit measurements were made at VOR, NEC and BNC consecutively. Strong winds occurred from an unusual northwesterly direction, also confirmed by meteorological balloon soundings in Trapani that indicate 12 $\mathrm{m} \mathrm{s}^{-1}$ (see http://weather.uwyo.edu/upperair/sounding.html). This allowed the plume to be traced for several hundred meters along the volcano flank as a descent was made from BNC by foot towards Torre del Filosofo (Figure 2). Near-downwind grounding plume was then sampled $\sim 1.5 \mathrm{~km}$ ( $\sim 2$ minutes plume travel) south-east from the summit. On 4 October, under similar wind conditions the instruments were co-deployed again at this near-downwind location.

\subsection{LOAC Optical Particle Counter and particle size distributions}

The LOAC (Light Optical Aerosol Counter) instrument operated is a new lightweight $(<1 \mathrm{~kg}$ ) OPC (Renard et al., 2016). Version 1.1 was used here. It detects scattered light from a laser $(650 \mathrm{~nm})$ at low angle 12 degree channel, whose signal is mostly independent of particle composition (Lurton et al., 2014). As well as the low angle channel used for particle counting and size attribution, the LOAC contains a second $\sim 60$ degree channel whose comparative signal can provide insight to the dominant particle nature in various size bins. This aspect is presented in Supplementary Material. Particles are counted and categorised according to scattered intensity into 19 size-bins between 0.2 and 50 (up to 100) $\mu \mathrm{m}$ diameter. The airflow is drawn through the instrument inlet by a miniature pump 2 $\mathrm{L} \mathrm{min}^{-1}$ (flow rate verified before and after each field deployment). The data acquisition rate is $\sim 0.1$ $\mathrm{Hz}$. A noise control and dark current calibration is performed each 15 min. Power was supplied by battery (replaced every few hours), and data logged to SD memory cards. Renard et al. (2016) report estimates of LOAC measurement uncertainties $(1 \sigma)$ in total number concentration due to stability of pump flow $( \pm 5 \%)$, laser $( \pm 5 \%)$, and detectors $( \pm 5 \%)$. In addition, size-calibration uncertainties are reported as $\pm 0.025 \mu \mathrm{m}$ for particles of size $<0.6 \mu \mathrm{m}, 5 \%$ for $0.7-2 \mu \mathrm{m}$, and $10 \%$ for particles $>2 \mu \mathrm{m}$. Renard et al. (2016) report a standard deviation of $\pm 15 \%(1 \sigma)$ in number concentration for total particles $<10 \mu \mathrm{m}$ when LOAC instruments are co-deployed over ten minutes. Poisson statistics on particle counting are $\pm 6 \%$ for particle concentrations $>1 \mathrm{~cm}^{-3}$. Additional uncertainties can occur for particles $<1 \mu \mathrm{m}$ at low particle counts (when signal is close to the detection limit) but such conditions are not expected in the aerosol-rich volcanic plume. Conversely, measurement coincidence errors can occur at too high particle count as shown in Section 3.3. Optimal weak-plume data is selected (and averaged) in the subsequent analysis (Section 3.4). For total integrated area and volume we assume an error-bar of $\pm 50 \%$ (Section 4.1 ). 
The LOAC measurements were fitted to lognormal particle size distributions using a least-squares procedure. We choose to fit a lognormal distribution, commonly used in atmospheric models: it enables to relatively simply interconvert number, area and volume, and to estimate effective radius across the whole distribution, even beyond the instrument measurement range. The best results were obtained with three modes, consistently with reported size distributions (Martin et al., 2008; see section 3.4). Equations for the lognormal aerosol distribution and effective radius are given in Appendix A3.

\subsection{Multi-Gas Instruments}

Two Multi-Gas instruments were deployed alongside the LOAC to measure $\mathrm{SO}_{2}$ mixing ratio (in ppmv, equivalent to $\mu \mathrm{mol} \mathrm{mol}^{-1}$ ) using three electrochemical sensors, and recorded other meteorological parameters. A direct exposure Multi-Gas (Roberts et al., 2017, based on Roberts et al., 2012), contained $\mathrm{SO}_{2}$ sensor versions SO2-A4 and SO2-AE, manufactured by Alphasense Sensor Technology Company, Ltd, with reported rms noise $<1.5 \mathrm{ppmv}$ for SO2-AE and 15 ppbv for SO2-A4 $( \pm 2 \sigma)$. The instrument used low noise electronics ( $3 \mathrm{mV}$ peak-to-peak) with the sensor output ( 0 to $2.5 \mathrm{~V}$ ) logged at 1-0.1 Hz using НОВO U12-006 datalogger (accuracy $\pm 2 \mathrm{mV} \pm 2.5 \%$ of absolute reading, precision $0.6 \mathrm{mV}$ ). The SO2-A4 has higher sensitivity (348 nA per ppmv) than SO2-AE (72 nA per ppmv) as determined by room-temperature pre-fieldwork calibrations, thus yields better resolution data (and stability). But it exhibits a lower range ( $\sim$ ppmv) compared to SO2-AE ( 38 ppmv), for the electronics board used. Thus, the SO2-A4 sensor is most accurate for the study of dilute plumes. The co-deployment of multiple $\mathrm{SO}_{2}$ sensors nevertheless provides opportunity for Multi-Gas intercomparison, see Supplementary Material. Temperature next to the sensors (close to ambient given no instrument heating) was monitored using a PT1000 resistance thermometer. Electrochemical sensor sensitivities are temperature dependent but at the ambient fieldtemperatures encountered $\left(10-15^{\circ} \mathrm{C}\right)$ the sensor sensitivity is within $3 \%$ of the calibrations $\left(a t 20^{\circ} \mathrm{C}\right)$ according to Alphasense specifications. A second Multi-Gas, with pumped design similar to that described by Shinohara et al. (2008), was co-deployed and contained another electrochemical sensor for $\mathrm{SO}_{2}$ (version 3ST/F, manufactured by City Technology, range 0-200 ppmv, repeatability $1 \%$, resolution $0.1 \mathrm{ppmv}$ ), and pressure and humidity sensors. Data were stored on a data-logger specifically designed by INGV-Palermo, able to sample at a frequency of $0.5 \mathrm{~Hz}$. The $\mathrm{H}_{2} \mathrm{O}$ measurement was determined as a function of $\mathrm{P}, \mathrm{T}$ and $\mathrm{RH}$ as suggested by the Buck (1981) equation, $\mathrm{E} 1$, where $T$ is the temperature $\left({ }^{\circ} \mathrm{C}\right), R H$ the relative humidity (percent), and $\mathrm{P}$ the pressure (hPa).

E1

$$
\left[\mathrm{H}_{2} \mathrm{O}_{(g)}\right]=6.1121 \cdot\left(1.0007+3.46 \cdot 10^{-6} \cdot P\right) \cdot \operatorname{Exp}\left[\frac{17.502 \cdot T}{240.97+T}\right] \cdot 10^{4} \cdot R H \cdot P^{-1}
$$

\subsection{PlumeChem model of plume BrO and OClO chemistry}

The PlumeChem box model (Roberts et al., 2009, 2014a) simulates the reactive halogen atmospheric chemistry of a dispersing plume in the troposphere, in a Lagrangian-type approach. The model 
includes detailed halogen chemistry (species: $\mathrm{BrO}, \mathrm{Br}, \mathrm{HBr}, \mathrm{BrONO}_{2}, \mathrm{HOBr}, \mathrm{BrCl}, \mathrm{BrNO}_{2}, \mathrm{BrNO}$, BrONO, $\mathrm{Cl}, \mathrm{HCl}, \mathrm{ClO}, \mathrm{OClO}, \mathrm{ClONO}_{2}, \mathrm{HOCl}$ ) as well as a background atmospheric scheme, with gasphase, photolytic and heterogeneous (gas-aerosol) reactions. The $\mathrm{BrNO}_{2}$ chemistry follows Roberts et al. (2014a), with less $\mathrm{BrNO}_{2}$ accumulation than Von Glasow (2010). The model initialisation around midday injected volcanic gases to an altitude of $\sim 3.5 \mathrm{~km}$. Ambient temperature was $285 \mathrm{~K}$ and windspeed set to $10 \mathrm{~m} \mathrm{~s}^{-1}$. Plume dispersion followed Pasquill-Gifford case C (Davidson et al., 1990). This is applicable for wind-speeds $>6 \mathrm{~m} / \mathrm{s}$ with strong insolation, or wind-speeds $3-6 \mathrm{~m} / \mathrm{s}$ with weakmoderate insolation. Both scenarios yield similar near-source plume $\mathrm{BrO} / \mathrm{SO}_{2}$ (Roberts et al., 2014a), although plume-air mixing is a source of uncertainty in the model chemistry, see Section 4.2. The simulated Mt Etna emission included $\mathrm{H}_{2} \mathrm{O}, \mathrm{CO}_{2}, \mathrm{HCl}, \mathrm{SO}_{2}, \mathrm{H}_{2} \mathrm{~S}, \mathrm{HBr}$ following Roberts et al. (2014a), with an $\mathrm{SO}_{2}$ flux of around $20 \mathrm{~kg} \mathrm{~s}^{-1}$. The emitted $\mathrm{HBr} / \mathrm{SO}_{2}=4.8 \times 10^{-4}\left(7.4 \times 10^{-4}\right.$ in sensitivity study $)$ was close to that recently reported at Etna BN crater by Wittmer et al. (2014), although it is noted that Mt Etna $\mathrm{HBr}$ emissions may be variable (Bobrowski and Guiffrida, 2012). This emission was modified to account for near-vent high-temperature chemistry using the HSC thermodynamic model to generate radicals including $\mathrm{OH}, \mathrm{Cl}, \mathrm{Br}, \mathrm{NO}_{x}$ and $\mathrm{SO}_{3}$. A 5:95 atmospheric:magmatic gas mixture was used, assuming $1050{ }^{\circ} \mathrm{C}$ magmatic temperature, see Roberts et al. (2014a) for tabulated Mt Etna emission and HSC output. This was followed by a further rapid dilution to crater-rim $\mathrm{SO}_{2}$ (tens of ppmv). Aerosol surface area was specified independently in the model initialisation as a function of humidity. The model was used to simulate near-source plume chemistry evolution over 20-30 min. In single box mode mixing of background air is provided at 10 s intervals by entrainment from a second box. Single box mode was used to simulate plume evolution for a range of background ozone (30-100 ppbv) and relative humidity (10-90\%). Multi-grid-box mode was used to provide horizontally spatially resolved plume composition for the two $\mathrm{HBr} / \mathrm{SO}_{2}$ emission ratios: in this setting, plume dispersion is simulated every $10 \mathrm{~s}$ across 130 grid-boxes of $38 \mathrm{~m}$ horizontal resolution, which expand in the vertical as air is entrained. For computational efficiency a half plume is simulated and reflected in a vertical plane of symmetry to yield the whole plume chemical composition. See Kelly et al. (2013) for a previous demonstration of this approach.

\section{Results: quantifying the primary volcanic aerosol emission from Mt Etna}

\subsection{High resolution time-series of aerosol volume co-measured with $\mathrm{SO}_{2}$}

Time-series of total aerosol volume co-measured with $\mathrm{SO}_{2}$ (Figure 3 ) show high plume exposures at the three summit craters VOR, NEC and $\mathrm{BNC}\left(\mathrm{SO}_{2}\right.$ up to $\sim 35 \mathrm{ppmv}$, causing the SO2-A4 sensor to saturate but detected by SO2-AE). As the descent was made along the flank into weaker (more dilute) plume, both the aerosol volume and $\mathrm{SO}_{2}$ decline. This confirms the volcanic aerosol source. Episodes of very high aerosol also occur especially during the descent by foot. These are not correlated to $\mathrm{SO}_{2}$. They are most likely resuspended dust generated during the descent, which could also be seen visually. Data were selected to minimise this dust contamination; the period (02 Oct 14:03-14:43) is labelled 'Flank'. Very weak plume was subsequently measured at $\sim 1.5 \mathrm{~km}$ downwind (see Figure 4 for details) with a dust-free period (02 Oct 16:13-16:36) labelled 'Vweak'. On 04 October, further near-downwind measurements were made (Figure 5) with two largely dust-free periods labelled 'DW1' (04 Oct 14:18 - 15:28) and 'DW2' (04 Oct 15:30 - 16:12), respectively (separated by an OPC instrument restart). These four time-periods (especially Vweak) form the basis 
for further analysis of the bulk plume. The individual crater-rim observations are not analysed in detail given probable OPC coincidence errors, see Section 3.3.

\subsection{Correlation in aerosol volume and $\mathrm{SO}_{2}$ and derivation of sulfate: $\mathrm{SO}_{2}$ ratios}

The strong correlation between measured total aerosol volume and volcanic $\mathrm{SO}_{2}$ is further shown by a scatter plot of the Vweak, Flank, DW1 and DW2 data (Figure 6). A least-squares linear regression on the Vweak data-set $\left(R^{2}=0.6\right)$ finds gradient $64.8 \mu \mathrm{m}^{3} \mathrm{~cm}^{-3}$ per ppmv $\mathrm{SO}_{2}$ with intercept $2.2 \mu \mathrm{m}^{3}$ $\mathrm{cm}^{-3}$. This regression line appears consistent with the Flank data, noting occasional dust episodes that elevate total volume. The regression line is also reasonably consistent with DW1 and DW2 datasets, although these exhibit more noisy signals in the smaller size bins, causing a volume offset at low particle number.

Our in-situ co-measurement of aerosol and $\mathrm{SO}_{2}$ enables further analysis of the real-time data to derive sulfate: $\mathrm{SO}_{2}$ ratios. The approach converts measured aerosol volume into sulfate concentration using the hygroscopic property weight-percent (wt\%) sulfate that is a strong function of humidity. We assume pure $\mathrm{H}_{2} \mathrm{SO}_{4 \text { (aq) }}$ or $\mathrm{NaHSO}_{4 \text { (aq) }}$ composition, deduced from reported timeaveraged sampling of Mt Etna aerosol (ash-poor conditions) by Martin et al. (2008). Parameterisations of wt\% sulfate and aerosol density as a function of humidity and temperature determined the $\mathrm{H}_{2} \mathrm{SO}_{4(\mathrm{aq})}$ molar volume (Table 3). This was used to convert measured aerosol volume into sulfate molar content (Table 4; see Appendix $\mathrm{A} 1, \mathrm{~A} 2$ ) hence sulfate: $\mathrm{SO}_{2}$ ratios (as $\mathrm{SO}_{2}$ was comeasured). The observed $64.8 \mu^{3}$ aerosol per ppmv $\mathrm{SO}_{2}$ during the Vweak period (measured at $1.8310^{19}$ molec. $\mathrm{cm}^{-3}, 11.9{ }^{\circ} \mathrm{C}$ and $38 \% \mathrm{RH}$ ) equates to a sulfate: $\mathrm{SO}_{2}$ molar ratio of $0.01-0.02$. This magnitude is consistent with reported filter-pack $\mathrm{SO}_{4}{ }^{2-}: \mathrm{SO}_{2}$ ratios $\left(0.017,0.049,0.05 \mathrm{~mol} \mathrm{~mol}^{-1}\right)$ at $\mathrm{Mt}$ Etna (Martin et al., 2008), with 1:100 typical at the volcano crater-rim (e.g. Mather et al., 2003). Also shown in Table 4 is a further sulfate: $\mathrm{SO}_{2}$ calculation based on selected data that minimises coincidence errors (see Section 3.3-3.4), yielding similar ( \pm 33\%) results.

Our analysis thereby establishes a quantitative link between filter-pack and real-time measurements of Mt Etna aerosol. This advances earlier work that established qualitative links between timeaveraged sampling and sun-photometer observations of Chilean volcanic aerosol (Mather et al., 2004b). Quantitative analysis of $\mathrm{SO}_{4}{ }^{2-} \mathrm{SO}_{2}$ requires that aerosol volume and $\mathrm{SO}_{2}$ are detected simultaneously within the same air mass, with $\mathrm{RH}$ and temperature also known. This was achieved here by in-situ sensor but is more challenging (and approximate) in remote sensing studies. Another condition is to reasonably constrain the aerosol volume within the measurement range. This was achieved in-situ here but seems rare in reported sun-photometer studies (Watson and Oppenheimer, 2000, 2001, Mather et al., 2004b), that may have sampled a more condensed and/or ash-rich plume. A key assumption is the $\mathrm{H}_{2} \mathrm{SO}_{4(\mathrm{aq})}$ or $\mathrm{NaHSO}_{4(\mathrm{aq})}$ particle composition that is based on earlier chemical sampling by Martin et al. (2008). The LOAC instrument can also provide insight into particle nature (based on optical properties at two scattering angles), finding a generally absorbing signal (see Supplementary Material). This may reflect trace impurities in the sulfate aerosol that either originate from the volcanic emission or from integration of small amounts of resuspended dust. For volcanic applications elsewhere the $\mathrm{SO}_{4}{ }^{2-}: \mathrm{SO}_{2}$ analysis method may need to be modified e.g. for metal-rich emissions where metal-acid reactions might instead lead to other compositions 
e.g. $\mathrm{Na}_{2} \mathrm{SO}_{4}, \mathrm{~K}_{2} \mathrm{SO}_{4}$, see Mather et al. (2003). For ash-rich plumes the particle volume measurement may be dominated by silica, which would obscure any estimation of sulfate. Volcanic $\mathrm{HNO}_{3}$ contributes little to sulfate aerosol volume as it partitions largely into the gas-phase under our highly acidic plume conditions (Roberts et al., 2009). Observations of Mt Etna near-source aerosol report low ammonium content (Martin et al., 2008) with little impact on aerosol volume, however ammonia and nitrate chemistry should be considered for emissions into the boundary layer that may be more ammonia-rich.

\subsection{Tracing of coincidence effects on the OPC measurement}

Total aerosol volume and $\mathrm{SO}_{2}$ are well correlated, however closer inspection of the particle number density of individual OPC size-bins shows evidence for non-linearities. Scatter plots of aerosol number with $\mathrm{SO}_{2}$ for both Vweak and Flank data are shown in Figure 7 for three size classes. We can observe a general positive correlation, but also evidence for non-linearities: for large particle size bins, more particles are counted at higher $\mathrm{SO}_{2}$ than expected from a linear regression. For small particle size bins, fewer particles are counted at higher $\mathrm{SO}_{2}$ than expected from a linear regression. These trends are even more marked in the strongest crater-rim plume, where in some cases the particle number time-series anti-correlates with that of $\mathrm{SO}_{2}$ (for raw data time-series see Supplementary Material). These non-linearities can also be seen in plots of normalized dV/dlogD as a function of particle size in Figure 8 (Flank and Vweak time-periods, where aerosol data has been

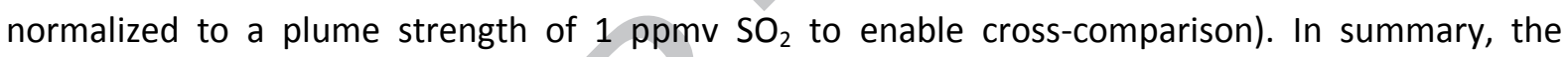
measured aerosol distribution has more large particles and fewer small particles in stronger plumes (as denoted by higher $\mathrm{SO}_{2}$ abundance). This effect cascades across the size-distribution as a function of plume strength.

These non-linearities manifest in different ways across the size bin range. They thus cannot be attributed to uncertainties in the $\mathrm{SO}_{2}$ measurement, also given the good agreement found between the Multi-Gas $\mathrm{SO}_{2}$ sensors (see Supplementary Material). Below we show that LOAC OPC coincidence errors can cause similar non-linearities in the aerosol measurement at high particle concentrations. We therefore cannot attribute the observed non-linearities (solely) to natural variability or microphysical processes.

At high aerosol concentrations signals from multiple particles may be simultaneously detected by the LOAC OPC. In the case of slightly overlapping signals this causes two particles to be counted as one, whose size is classified as that of the larger particle, whilst the smaller particle is not counted, i.e. a 'shadow effect'. Where signals overlap considerably and add together, the two observed particles may be classified as an even larger single particle. This 'non-quantitative counting', also known as 'coincidence errors' is a known OPC uncertainty; it can restrict the total number of particles counted as discussed by Renard et al. (2016) for the LOAC. Similar coincidence errors prevented a true aerosol estimate in a previous OPC deployment at Mt Etna (Vance et al., 2010). Here, the LOAC OPC measurements span plume strength over two orders of magnitude ( 0.3 to 30 ppmv $\mathrm{SO}_{2}$ ) enabling the effect to be traced and characterised. The magnitude of the effect diminishes as plume strength decreases, and is least apparent for the Vweak dataset. 
To further quantify the role of coincidence errors, a simple statistical model of the LOAC OPC is presented alongside the Vweak volumic size distribution on a linear $y$-axis scale (Figure 9). This model simulates how particles at a specified model input size distribution give rise to a detected signal electronically sampled at $40 \mathrm{kHz}$. The strong similarity between the "modelled measured" size distribution and the observations suggests that coincidence errors can significantly impact LOAC aerosol measurements in concentrated plumes. To further quantify the Mt Etna aerosol size distribution and derive fluxes we select optimal data at low plume strength $\left(\mathrm{SO}_{2}=0.3-0.4 \mathrm{ppmv}\right)$, least affected by coincidence errors.

\subsection{Quantifying Mt Etna primary aerosol size distribution and emission flux}

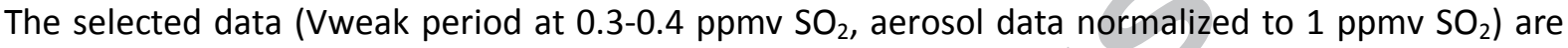
presented in Figures 10 and 11 (lognormal and linear y-axis scales, respectively) as number, area and volume distributions (where area under the $d[] / d \log D$ vs log-scale Diameter (D) curves corresponds to total integrated number, area or volume). Measurements for each $10 \mathrm{~s}$ period (shown as connected data-points in blue) exhibit variation, some of which may be due to imperfect normalization using the Multi-Gas $\mathrm{SO}_{2}$ observations. The smallest size-bin exhibits greatest data scatter (standard deviation in number $=500 \mathrm{~cm}^{-3}$ ). The distribution shape is more easily seen by taking the mean average of each size-bin (black dots with standard error in mean). The data show a tri-modal size distribution with volume maxima around 1-2, 0.6-07 and 0.3-0.4 $\mu \mathrm{m}$. This volumic distribution is consistent with reported time-averaged sulfate sampling (Martin et al., 2008): both exhibit maxima at supramicron particle sizes.

The measured distribution within the instrument range appears to constrain relatively well particle volume. This enables a tri-modal lognormal distribution to be fitted (black lines in Figures 10-11, see Appendix A3 for definition), whose parameters $\left(N, D_{N}, \sigma_{g}\right.$ for each mode) are given in Table 5. Our lognormal distribution fit incurs some uncertainty in the volume peak maximum between 1-2 $\mu \mathrm{m}$ (where LOAC size bin resolution is low), and in the smallest particle mode (as the smallest size-bin is subject to greatest measurement uncertainty). Nevertheless, the distribution shows distinct supraand submicron modes, with dN/dLogD shape bearing similarity to that of Allen et al. (2006) and Shcherbakov et al. (2016).

The lognormal particle size distribution fitting facilitates comparison of different observations. This approach has been used for the fine silicate aerosol fraction at Mt Etna (Martin et al., 2008), finding a modal diameter $\left(D_{N}=0.14 \mu \mathrm{m}\right)$ slightly smaller than the overall particle distribution measured in this study $\left(D_{N}=0.2-1.14\right.$ across the three modes) but with similar geometric standard deviation $\left(\sigma_{\mathrm{g}}=\right.$ 1.3-1.45). Further comparison in terms of particle number flux is given below. Lognormal distributions were also fitted to aircraft measurements of Eyjafjallajökull plume aerosol (Schumann et al., 2011, Johnson et al., 2012). In contrast to our study the plume was aged and ash-rich. It contained fine and coarse mode particles, with overall $R_{\text {eff }}=0.1-1 \mu \mathrm{m}\left(R_{\text {eff }}=0.3 \mu \mathrm{m}\right.$ in our study; Table 5). The coarse-mode was of several microns diameter (volumic modal diameter $D_{V}=3.2-4.5$ ), i.e. greater in size than our study and with greater geometric standard deviation $\left(\sigma_{\mathrm{g}}=1.8-1.9\right)$. It showed a high silica (ash) composition. These authors also highlight deviation of the coarse aerosol distribution from the lognormal, probably due to large particle sedimentation. 
Our volcanic aerosol measurement at Mt Etna made $\sim 1.5 \mathrm{~km}$ downwind (with only limited time for deposition or microphysics processes) most likely reflects the primary volcanic aerosol emission. It is compared to lognormal distributions of representative atmospheric aerosols in Figure 12 (urban, rural, desert dust storm, marine, polar; Jaenicke, 1993; note actual aerosol may deviate from the representative distributions due to temporal/geographic variability). Importantly, our volcanic

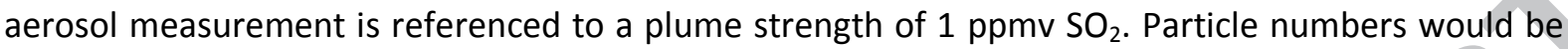
proportionally higher in stronger plume and lower in more dilute plume. At $1 \mathrm{ppmv} \mathrm{SO}_{2}$ plume strength, the volcanic submicron aerosol concentration reaches similar levels to representative urban conditions, and the supra-micron aerosol concentration exceeds them. Only a desert dust storm contains more particles of micron size.

The lognormal fit parameters were used to calculate total integrated volume, area, and number (Table 5). The analysis does not consider very fine nanometer-sized particles. Such particles are likely important in terms of number but are not expected to contribute significantly to volume nor surface area (Ammann and Burtscher, 1993). Aerosol/ $/ \mathrm{SO}_{2}$ ratios can then easily be obtained as $\mathrm{SO}_{2}$ was comeasured (Table 5). Emission fluxes are estimated by combining the aerosol/ $/ \mathrm{SO}_{2}$ ratios with the $\mathrm{SO}_{2}$ flux from the INGV Ultraviolet scanning spectrometer FLAME network installed at Mt Etna (Salerno et al., 2009), that reports 1800 to 2100 tonnes day $\mathrm{SO}_{2}$ during the measurement campaign, a typical $\mathrm{SO}_{2}$ emission flux for Mt Etna passive degassing.

Assuming a mean $\mathrm{SO}_{2}$ flux of 1950 tonnes/day, the estimated sulfate aerosol volume flux is $5.0 \times 10^{14}$ $\mu \mathrm{m}^{3} \mathrm{~s}^{-1}$ and particle area flux $4.9 \times 10^{15} \mu \mathrm{m}^{2} \mathrm{~s}^{-1}$. The number flux is $1.5 \times 10^{16} \mathrm{~s}^{-1}$, which is a lower limit that excludes numerous fine $\mathrm{nm}$ particles. Nevertheless, the study shows Mt Etna's sulfate particle number flux vastly exceeds the total number flux of silica particles from Mt Etna of $10^{12} \mathrm{~s}^{-1}$ (Martin et al., 2008). This is consistent with ash-poor quiescent degassing. The particle volume flux is converted to mass flux using an $\mathrm{H}_{2} \mathrm{SO}_{4}$ (aq) density of $1.39 \mathrm{~g} \mathrm{~cm}^{-3}$ (calculated for the observed $40 \% \mathrm{RH}$ using parameterisation of Tabazadeh et al. (1997); see Appendix A1) to yield $0.7 \mathrm{~kg} \mathrm{~s}^{-1}$. This contrasts by an order of magnitude with the Mt Etna sun-photometer measurements of Watson and Oppenheimer (2000) who estimated particle mass fluxes of 4.5-8 $\mathrm{kg} \mathrm{s}^{-1}$ as a lower limit (assuming a water mode with density = 1 and sulfate mode with density $1.67 \mathrm{~g} \mathrm{~cm}^{-3}$ ). One possible explanation is that two of the summit craters were exhibiting mild strombolian activity (small explosions with ash) during the field-measurements of Watson and Oppenheimer (2000), whereas our study quantifies sulfate-rich aerosol from Mt Etna during passive degassing. But it is also emphasized that volcanic sulfate aerosol is highly hygroscopic therefore volume and surface area fluxes depend strongly on relative humidity. Calculations to estimate the humidity dependence of volcanic aerosol and its role in plume chemistry are given in Section 4.

\section{Discussion: role of primary volcanic aerosol on plume halogen chemistry}

\subsection{Aerosol hygroscopic growth as a function of humidity}

Observations of hygroscopic aerosols in Mt Etna plume are most usefully interpreted in the context of the local humidity conditions. Volcanic emissions are $\mathrm{H}_{2} \mathrm{O}$-rich, and typically initially condensed, becoming visually transparent upon dispersion as the plume dilutes (unless ambient $\mathrm{RH}$ is high). The 
Mt Etna emission consisted of $\sim 80-95 \% \mathrm{H}_{2} \mathrm{O}$ with $\mathrm{SO}_{2}$ 1-5\% (Roberts et al., 2017). The plume was

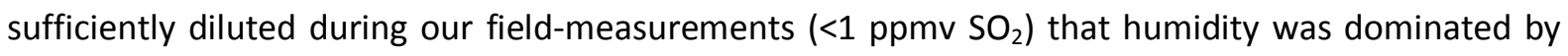
background $\mathrm{RH}$. Here we perform calculations to estimate how the primary aerosol size distribution grows and shrinks as a function of humidity. We use the measured size distribution with fitted lognormal distribution (Figures $10-11)$ at known humidity $(40 \% \mathrm{RH})$ and apply parameterisations of particle volume over a humidity range. Aerosol sulfate content was first calculated as per Section 3.2 , and $\mathrm{H}_{2} \mathrm{SO}_{4(\mathrm{aq})}$ attributed proportionally across the $(0.01 \mu \mathrm{m}$ discretized) volumic fitted lognormal size distribution. The volume (in each $0.01 \mu \mathrm{m}$ size-bin) was then re-calculated for a range of $\mathrm{RH}$ ranging from 0.1 to $99 \%$ using the $\mathrm{H}_{2} \mathrm{SO}_{4(\mathrm{aq})}$ molar volume parameterisation of Appendix A1. For each $\mathrm{RH}$ calculation, area and number were simply calculated from the new volume distributions. The calculation assumes $\mathrm{H}_{2} \mathrm{SO}_{4(\mathrm{aq})}$ in equilibrium with $\mathrm{RH}$ for planar surfaces (aerosol curvature is relevant for very small particles only and is omitted for simplicity). Similar results are also found for $\mathrm{NaHSO}_{4(\text { (aq) }}$ (not shown). Both $\mathrm{H}_{2} \mathrm{SO}_{4(\text { aq) }}$ and $\mathrm{NaHSO}_{4(\text { (aq) }}$ are highly hygroscopic, thus expected to be in the aqueous-phase (Martin et al., 2003, Tang and Munkelwitz, 1994). Ammonium sulfate can show aqueous-solid hysteresis effects but it is not expected in the near-source Mt Etna plume (nor observed: Martin et al., 2008) given high sulfate concentrations and low background ammonia. The hygroscopic aerosol growth calculation does not include $\mathrm{HCl}$ partitioning to aqueous-phase that can further enhance aerosol volume at very high RH (> 85\%), see Martin et al. (2012) and Roberts et al. (2014b).

Figure 13a shows that particle number is conserved as the distribution shifts to higher sizes with greater $\mathrm{RH}$. Aerosol surface area and volume both increase with $\mathrm{RH}$, with substantial enhancements at $\mathrm{RH}>90 \%$ (Figure 13b,c). The distribution remains tri-modal. However, at high $\mathrm{RH}$ all aerosol volumic maxima occur at supra-micron sizes $(\sim 1-10 \mu \mathrm{m})$, whilst at low RH there is only one volumic maximum at supramicron size ( $\sim$ few $\mu \mathrm{m})$. We suggest this RH dependency is likely a contributing factor to the different size distributions reported from Mt Etna to date (see Tables 1-2), noting Mather et al. (2004b) proposed condensation as an important control on particle size at volcanoes elsewhere (Villarrica, Lascar). Other sources of variability include volcanic activity (e.g. ash-poor/ashrich) and microphysics/secondary aerosol for aged plumes.

Aerosol surface area is an important control on plume chemistry (see Section 1.2) but has been little quantified by studies to date. An estimate of the primary volcanic aerosol surface area and its $\mathrm{RH}$ dependency is provided in Figure 14 based on the observed aerosol and lognormal distribution at $40 \% \mathrm{RH}, 285 \mathrm{~K}$ and the hygroscopic-growth calculations (see Table 5 and Figure 13b). The primary aerosol surface area relative to $\mathrm{SO}_{2}$ is around $2 \times 10^{-11} \mu \mathrm{m}^{2}$ per molecule $\mathrm{SO}_{2}$ (equivalent to $10^{3} \mathrm{~cm}^{2}$ per mole $\mathrm{SO}_{2}$ ) at $40 \% \mathrm{RH}$. This is an order of magnitude lower than derived from reported sunphotometer measurements of near-source (1-min) plume from Villarrica volcano during Strombolian activity (Mather et al., 2004b). As mentioned above, both ash and humidity conditions affect the size distribution hence surface area.

Figure 14 predicts the humidity dependency of surface area and volume to be moderately positive below $85 \% \mathrm{RH}$ with a very strong enhancement above $90 \% \mathrm{RH}$. This predicted trend is similar to $\mathrm{H}_{2} \mathrm{SO}_{4(\text { aq) }}$ growth factors e.g. as reported by Li et al. (2001). We note our study did not observe aerosol growth/water content at Mt Etna to test these calculations, nor characterise possible day-today/crater-to-crater variability in the primary aerosol emission. Below we apply the calculated $\mathrm{RH}$ 
dependence of the primary aerosol surface area in a numerical model to investigate its influence on reactive halogen chemistry in the near-downwind plume.

\subsection{Surface area-humidity controls on Mt Etna plume BrO, OClO chemistry}

In a model sensitivity study we investigate the effect of ambient relative humidity on plume chemistry due to its predicted influence on aerosol surface area (Figure 14) as a control on the rate of heterogeneous reactions R1 and R2. Simulations are shown for three background atmosphere scenarios with differing ozone content as well as ambient humidities (Figure 15), for downwind plume evolution over $20 \mathrm{~min}$. We compare the model sensitivity study to recently reported observations of Mt Etna plume chemistry: the trend in near-source plume ozone depletion quantified by Surl et al. (2015) using in-situ observations in July-August 2012 is shown as a thick yellow line. Remote sensing DOAS observations of near-downwind plume $\mathrm{OClO} / \mathrm{SO}_{2}$ alongside $\mathrm{BrO} / \mathrm{SO}_{2}$ made in August-September 2012 by Gliß et al. (2015) are shown as dark green data points, demonstrating an increase followed by a plateau in $\mathrm{BrO} / \mathrm{SO}_{2}$ as the plume travels downwind. Their observations of plume OClO build on the first discovery of OClO at Mt Etna by Bobrowski et al. (2007). $\mathrm{OClO} / \mathrm{SO}_{2}$ increases from below detection limit (light green data points) to around $3 \times 10^{-5}$ $\mathrm{mol} / \mathrm{mol}$ (dark green data points) over a few minutes.

The observed increase in $\mathrm{BrO} / \mathrm{SO}_{2}$ is well reproduced by the model although the subsequent $\mathrm{BrO} / \mathrm{SO}_{2}$ plateau is slightly overestimated towards the end of the simulation. Near-downwind plume ozone depletion is also well reproduced, with the model predicting a partial recovery further downwind. The box model also succeeds in simulating $\mathrm{OClO} / \mathrm{SO}_{2}$ in broad agreement with that observed (within an order of magnitude), with $\mathrm{OClO} / \mathrm{SO}_{2}$ increasing to a maximum several minutes downwind. This modelling capability for reactive chlorine had not been demonstrated previously.

The model predicts that relative humidity enhances $\mathrm{BrO}$ in the downwind plume, but has a rather small influence on BrO near to source. This is initially surprising given the well-known importance of volcanic aerosol surface area in catalysing the formation of BrO (Bobrowski et al., 2007, Roberts et al., 2009, Von Glasow, 2010). A model explanation is provided, based on the predicted Br-speciation of Roberts et al. (2014a): whilst reactive bromine formation is strongly aerosol-dependent, the neardownwind $\mathrm{BrO} / \mathrm{SO}_{2}$ is instead largely controlled by aerosol-independent cycling between $\mathrm{Br}$ and $\mathrm{BrO}$ (reactions R4 and R7). This mechanism may provide an explanation for the lack of correlation between ambient $\mathrm{RH}$ and $\mathrm{BrO} / \mathrm{SO}_{2}$ in $\mathrm{Mt}$ Etna plume at $6 \mathrm{~km}$ downwind reported by Bobrowski and Guiffrida (2012). Further downwind, $\mathrm{BrO} / \mathrm{SO}_{2}$ is controlled by partitioning between $\mathrm{HOBr}, \mathrm{BrONO}_{2}$ and $\mathrm{BrO}$ (reactions R1-R6), whose interconversion does depend on aerosol. Hence higher $\mathrm{RH}$ promotes $\mathrm{BrO} / \mathrm{SO}_{2}$ far downwind. A greater rate of ozone depletion is also predicted at higher $\mathrm{RH}$, as the enhanced surface area yields a higher rate of reactive bromine cycling. Figure 15 shows that near-downwind $\mathrm{OClO} / \mathrm{SO}_{2}$ is enhanced at higher $\mathrm{RH}$. This reflects the role of aerosol in the conversion of volcanic $\mathrm{HBr}$ into reactive halogens: a faster depletion of $\mathrm{HBr}$ (and $\mathrm{Br}^{-}$(aq)) at high $\mathrm{RH}$ promotes formation of $\mathrm{BrCl}$ from reaction $\mathrm{R} 2$. Reactive chlorine formation is thus greater at higher surface area or $\mathrm{RH}$. An interesting model finding is the influence of background atmospheric composition on plume $\mathrm{OClO}$. Plumes dispersing into a more polluted $\mathrm{O}_{3}$-rich troposphere produce more OClO. The model explanation is that OClO production requires formation of $\mathrm{ClO}$ (alongside 
$\mathrm{BrO}$ ), which is produced from reaction of $\mathrm{Cl}$ with ozone in competition with loss of $\mathrm{Cl}$, e.g. by reaction with $\mathrm{CH}_{4}$. The plume reactive halogen chemistry itself depletes ozone, nevertheless a more $\mathrm{O}_{3}$-rich background atmosphere will yield higher absolute in-plume ozone concentrations and hence more OCIO.

Further insights are gained from the spatially resolved model simulations (Figure 16 and 17). The halogen cycling is most rapid in the plume centre, where $\mathrm{Br}$ and $\mathrm{BrO}$ absolute concentrations are the highest, causing greatest ozone loss. As consequence reactive bromine partitions to $\mathrm{Br}$ and the $\mathrm{BrO} / \mathrm{SO}_{2}$ ratio is diminished in the plume centre compared to the plume edge. OClO is also slightly enhanced at the plume edge, the region where $\mathrm{BrO}$ and plume ozone (required to form $\mathrm{ClO}$ from $\mathrm{Cl}$ ) are more abundant. This pattern concurs with reported measured spatial trends in $\mathrm{BrO} / \mathrm{SO}_{2}$ and OClO/SO ${ }_{2}$ (Bobrowski et al., 2007, General et al., 2015, Gliss et al., 2015). Simulations with higher bromine emission (Figure 17) show greater $\mathrm{BrO} / \mathrm{SO}_{2}$ and ozone depletion but a delayed rise in $\mathrm{OClO} / \mathrm{SO}_{2}$. This is due to the delayed depletion of $\mathrm{HBr}$ thus later onset of $\mathrm{BrCl}$ formation, as well as to the lower in-plume ozone.

Overall, the model shows a good general capability to reproduce these Mt Etna plume observations although it is emphasized that the model parameter space is vast. Several aspects of the emissionplume are only partially constrained and may vary with volcanic or meteorological conditions. These include the high-temperature emission-initialisation, extents of plume-air mixing, and bromine- $\mathrm{NO}_{x}$ chemical coupling, as discussed by Roberts et al. (2014a) and Surl et al. (2015). Our measurement of the primary volcanic aerosol emission (and its surface area) informs one important aspect of this complex parameter space (but we did not investigate particle processing/secondary aerosol which will become increasingly important as the plume disperses downwind). Besides aerosol observations, measurements of additional reactive halogen species beyond $\mathrm{BrO}$ and $\mathrm{OClO}$ are needed to help better constrain volcanic plume chemistry models.

\section{Conclusions}

Volcanoes are an important source of aerosols to the troposphere impacting atmospheric chemistry and possibly climate evolution. Reactions on the aerosol surface area catalyse the conversion of coemitted volcanic halogens $(\mathrm{HBr}, \mathrm{HCl})$ into reactive forms $(\mathrm{BrO}, \mathrm{OClO})$ that deplete ozone. The primary volcanic aerosol emission is an important driver of this process but has been only partially quantified by studies to date of quiescently degassing (ash-poor) volcano plumes. This presents a limitation to initialising models of volcano plume atmospheric impacts. We present a high-resolution $(0.1 \mathrm{~Hz})$ real-time in-situ study at Mt Etna during passive degassing that co-deployed a LOAC optical particle counter (with 19 size-bins over $0.2-50 \mu \mathrm{m}$ in diameter) to characterise the aerosol number and sizedistribution alongside Multi-Gas $\mathrm{SO}_{2}$ sensors, Figures 3-5. The in-situ aerosol/ $\mathrm{SO}_{2}$ is combined with remote sensing $\mathrm{SO}_{2}$ flux to yield aerosol emission flux. Our data analysis focuses on near-downwind $(\sim 1.5 \mathrm{~km})$ grounding volcanic plume, having traced OPC coincidence errors in the more concentrated plume measured nearer-to-source that affect the aerosol size distribution retrieval (Figures 7-9).

Total particle volume correlated strongly with $\mathrm{SO}_{2}$ (as a plume tracer), Figure 6. Further analysis is performed assuming the volcanic aerosol volume is dominated by $\mathrm{H}_{2} \mathrm{SO}_{4(\mathrm{aq})}$ or $\mathrm{NaHSO}_{4(\mathrm{aq})}$ : by analysing the co-measured volcanic aerosol and $\mathrm{SO}_{2}$ we derive $\mathrm{SO}_{4}{ }^{2-} / \mathrm{SO}_{2}$ ratios of $1-2 \%$ that are 
consistent with values reported from filter-pack aerosol sampling, Table 4. A multi-modal volcanic aerosol size distribution is identified at $40 \% \mathrm{RH}$, with volume median diameters 1-2, 0.6-07 and 0.3$0.4 \mu \mathrm{m}$, Figures 10-11, Table 5. Episodes of re-suspended dust were also observed that generated larger particles. Lognormal fits to the observed volcanic particle size distribution provide parameters for initialisation of atmospheric models and enable the primary aerosol emission from Mt Etna to be compared to other reported distributions. At 1 ppmv $\mathrm{SO}_{2}$ plume strength, the volcanic submicron aerosol concentration reaches similar levels to representative urban conditions, and the supramicron aerosol concentration exceeds them, Figure 12.

Hygroscopic calculations predict that total surface area of the primary aerosol emission becomes strongly enhanced at high relative humidity, Figure 13-14. A numerical model of the plume atmospheric chemistry is used to evaluate the role of primary aerosol surface area and its humidity dependence on volcanic plume $\mathrm{BrO}$ and $\mathrm{OClO}$ chemistry, Figures 15-17. On near-downwind (a few $\mathrm{km}$ ) scales $\mathrm{BrO} / \mathrm{SO}_{2}$ is simulated to have little dependence on ambient $\mathrm{RH}$. This surprising finding that can be explained by the model chemistry - is of value to interpreting volcanic BrO monitoring data. Aerosol and $\mathrm{RH}$ exert stronger controls on $\mathrm{OClO}$ and on $\mathrm{BrO}$ further downwind. Alongside $\mathrm{BrO}$ formation and ozone depletion, $\mathrm{OClO}$ formation is simulated in broad quantitative agreement with recent $\mathrm{Mt}$ Etna observations. $\mathrm{OClO} / \mathrm{SO}_{2}$ reaches a maximum a few minutes downwind. High background ozone is shown to promote $\mathrm{OClO}$ formation whilst a high volcanic $\mathrm{HBr}$ emission delays the rise in $\mathrm{OClO} / \mathrm{SO}_{2}$. The model plume chemistry predicts strong spatial variations between plume edge and centre demonstrating the role of plume-air mixing.

This study focuses on the size distribution of primary aerosol from passively degassing Mt Etna volcano, measured just $1.5 \mathrm{~km}, \sim 2$ min from the crater. Using the same LOAC instrumentation operated on a balloon we have very recently also reported aerosol size distributions in relatively young tropospheric plume $(8 \mathrm{~km}, \sim 15 \mathrm{~min})$ downwind from the Icelandic Holuhraun effusive eruption (Vignelles et al., 2016). Interestingly, both studies show evidence for supra- and sub-micron modes with the sub-micron mode relatively more enhanced for the more aged plume case. This might reflect an expected consequence of in-plume atmospheric oxidation of $\mathrm{SO}_{2}$. However, we emphasize that in each case the primary aerosol emission likely depends on many factors (near-vent mixing, temperature, magmatic composition, etc.) that are specific to the volcanic source.

\section{Acknowledgements}

This study was financed by LABEX VOLTAIRE (VOLatils-Terre Atmosphère Interactions - Ressources et Environnement) ANR-10-LABX-100-01 (2011-20). We are grateful to Alphasense Ltd for sensor advice and thank $M$ Tagger and B. Scaillet for initiating this project. We thank J. Gli $\beta$ and N. Bobrowski for providing plume observation data from Gliß et al. (2015), and for useful discussions. TJR acknowledges The Aerosol Society and Darwin College, who supported her attendance of the "Halogens in Volcanic Systems" workshop that informed this project's research goals. AA acknowledges funding from the European Research Council under the European Union's Seventh Framework Programme (FP7/2007/2013)/ERC grant agreement nr 305377. We thank A. Amantia, M. Cantarero and G. Spata for fieldwork assistance and T. Caltabiano for assistance in gas flux data processing. This study contributes to ChArMEx (the Chemistry-Aerosol Mediterranean Experiment) 
WP1 on atmospheric emissions in the Mediterranean region, as well as ANR-STRAP (Transdisciplinary collaboration to investigate volcano plumes risks).

\section{References}

Allen A. G., Mather T. A., McGonigle A. J. S., Aiuppa A., Delmelle P., Davison B., Bobrowski N., Oppenheimer C., Pyle D. M. and Inguaggiato S. (2006) Sources, size distribution and downwind grounding of aerosols from Mt Etna. J. Geophys. Res. 111, D10302, doi: 10.1029/2005JD006015.

Ammann M. and Burtscher H. (1993) Aerosol dynamics and light-scattering properties of a volcanic plume. J. Geophys. Res. 98, 19705-19711.

Ammann M., Hauert R., Burtscher H. and Siegmann H. C. (1993) Photoelectric charging of ultrafine volcanic aerosols: Detection of $\mathrm{Cu}(\mathrm{I})$ as a tracer of chlorides in magmatic gases. J. Geophys. Res. 98, 551-556.

Bobrowski N. Von Glasow R., Aiuppa A., Inguaggiato S., Louban I., Ibrahim O. W. and Platt U. (2007) Reactive halogen chemistry in volcanic plumes. J. Geophys. Res.: Atmos. 112, D6, D06311, doi:10.1029/2006JD007206.

Bobrowski N. and Guiffrida G. (2012) Bromine monoxide / sulphur dioxide ratios in relation to volcanological observations at Mt. Etna 2006-2009. Solid Earth 3, 433-445, doi:10.5194/se3-433-20122012.

Buck A. L. (1981) New equations for computing vapor pressure and enhancement factor. J. Appl. Meteorol. 20, 1527-1532.

Bussinger S., Huff R., Pattantyus A., Horton K., Sutton A. J., Elias T. and Cherubini T. (2015) Observing and Forecasting Vog Dispersion from Kīlauea Volcano, Hawaii. Bull. Am. Meteor. Soc. 96, 10, 1667-1686.

Carn S. A., Froyd K. D., Anderson B. E., Wennberg P., Crounse J., Spencer K., Dibb J. E., Krotkov N. A., Browell E. V., Hair J. W. and Diskin G. (2011) In situ measurements of tropospheric volcanic plumes in Ecuador and Colombia during TC4. J. Geophys. Res.: Atmos. 116, D10.

Davidson G. A. (1990) A modified power law representation of the Pasquill-Gifford dispersion coefficients, J. Air Waste Manage. Assoc. 40,1146-1147.

Donovan A, Tsanev V, Oppenheimer C, Edmonds M. (2014) Reactive halogens (BrO and OClO) detected in the plume of Soufrière Hills Volcano during an eruption hiatus. Geochem. Geophys. Geosyst. 15, 3346-3363.

Ebmeier S. K., Sayer A. M., Grainger R. G., Mather T. A. and Carboni, E. (2014) Systematic satellite observations of the impact of aerosols from passive volcanic degassing on local cloud properties. Atmos. Chem. Phys. 14, 10601-10618, doi:10.5194/acp-14-10601-2014. 
General S., Bobrowski N., Pöhler D., Weber K., Fischer C. and Platt U. (2015) Airborne I-DOAS measurements at Mt. Etna: $\mathrm{BrO}$ and $\mathrm{OClO}$ evolution in the plume. J. Volcanol. Geotherm. Res. 300, 175-186.

Gliß J., Bobrowski N., Vogel L., Pöhler D. and Platt U. (2015). OCIO and BrO observations in the volcanic plume of Mt. Etna-implications on the chemistry of chlorine and bromine species in volcanic plumes. Atmos. Chem. Phys. 15, 5659-5681.

Halmer M. M., Schmincke H.-U., and Graf H.-F. (2002) The annual volcanic gas input into the atmosphere, in particular into the stratosphere: a global data set for the past 100 years. J. Volcanol. Geotherm. Res. 115, 511-528.

Ilyinskaya E., Oppenheimer C., Mather T. A., Martin R. S. and Kyle P. R. (2010) Size-resolved chemical composition of aerosol emitted by Erebus volcano, Antarctica. Geochem. Geophys. Geosyst. 11, Q03017, doi:10.1029/2009GC002855.

Jaenicke R. (1993) Tropospheric aerosols. In Aerosol-Cloud-Climate Interactions (Ed. P. V. Hobbs), Academic Press, 1-31.

Johnson B., Turnbull K., Brown P., Burgess R., Dorsey J. Baran A. J., Webster H., Haywood J., Cotton R., Ulanowski Z., Hesse E., Woolley A. and Rosenberg P. (2012) In situ observations of volcanic ash clouds from the FAAM aircraft during the eruption of Eyjafjallajökull in 2010. J. Geophys. Res. 117, D00U24, doi:10.1029/2011JD016760.

Jourdain L., Roberts T. J., Pirre M. and Josse B. (2016) Modeling the reactive halogen plume from Ambrym volcano and its impact on the troposphere with the CCATT-BRAMS mesoscale model. Atmos. Chem. Phys. 16, 12099-12125.

Kelly P. J., Kern C., Roberts T. J., Lopez T., Werner C. and Aiuppa A. (2013) Rapid chemical evolution of tropospheric volcanic emissions from Redoubt Volcano, Alaska, based on observations of ozone and halogen-containing gases. J. Volcanol. Geotherm. Res. 259, 317-333.

Kroll J. H., Cross E. S., Hunter J. F., Pai S., Wallace L. M., Croteau P. L., Jayne J. T., Worsnop D. R., Heald C. L., Murphy J. G., and Frankel S. L. (2015) Atmospheric evolution of sulfur emissions from Kılauea: real-time measurements of oxidation, dilution, and neutralization within a volcanic plume. Environmental Science \& Technology, 49, 7, 4129-37.

Li J., Wong J. G., Dobbie J.S. and Chýlek P. (2001) Parameterization of the optical properties of sulfate aerosols. J. Atmos. Sci. 58, 193-209.

Lurton T., Renard J.-B., Vignelles D., Jeannot M., Akiki R., Mineau J.-L. and Tonnelier T. (2014) Light scattering at small angles by atmospheric irregular particles: modelling and laboratory measurements. Atmos. Meas. Tech. 7, 931-939, doi:10.5194/amt-7-931-2014.

Martin, S.T., Schlenker, J.C., Malinowski, A., Hung, H.M. and Rudich, Y. (2003) Crystallization of atmospheric sulfate-nitrate-ammonium particles. Geophysical research letters, 30, 21, 2102, doi:10.1029/2003GL017930. 
Martin R. S., Mather T. A. and Pyle D. M. (2006) High-temperature mixtures of magmatic and atmospheric gases. Geochem. Geophys. Geosyst. 7, Q04006, doi:10.1029/2005GC001186.

Martin R. S., Mather T. A., Pyle D. M., Power M., Allen A. G., Aiuppa A., Horwell C. J. and Ward E. P. W. (2008) Composition-resolved size distributions of volcanic aerosols in the Mt. Etna plumes. J. Geophys. Res. 113, D17211, doi:10.1029/2007JD009648.

Martin R. S., Roberts T. J., Mather T. A. and Pyle D. M. (2009) The implications of H 2 S and H 2 kinetic stability in high-T mixtures of magmatic and atmospheric gases for the production of oxidized trace species (eg, BrO and $\mathrm{NO}_{\mathrm{x}}$ ). Chem. Geol. 263, 143-150.

Martin R. S., Wheeler J. C., Ilyinskaya E., Braban C. F. and Oppenheimer C. (2012) The uptake of halogen $(\mathrm{HF}, \mathrm{HCl}, \mathrm{HBr}$ and $\mathrm{HI})$ and nitric $\left(\mathrm{HNO}_{3}\right)$ acids into acidic sulfate particles in quiescent volcanic plumes. Chem. Geol. 296, 19-25.

Martin R. S., Ilyinskaya E. and Oppenheimer C. (2012) The enigma of reactive nitrogen in volcanic emissions. Geochim. Cosmochim. Acta 95, 93-105.

Mather T.A., Allen A. G., Oppenheimer C., Pyle D. and McGonigle A. J. S (2003) Size-resolved characterisation of soluble ions in the particles in the tropospheric plume of Masaya Volcano, Nicaragua: Origins and plume processing. J. Atmos. Chem. 46, 207-237.

Mather T. A., Pyle D. M. and Oppenheimer C. (2004a) Tropospheric volcanic aerosol.In Volcanism and the Earth's Atmosphere (Eds. A. Robock and C. Oppenheimer), American Geophysical Union Monograph Series 139, 189-212.

Mather T. A., Tsanev V. I., Pyle D. M., McGonigle A. J. S., Oppenheimer C. and Allen A. G. (2004b) Characterization and evolution of tropospheric plumes from Lascar and Villarrica volcanoes, Chile. J. Geophys. Res., 109, D21303.

Mather T. A., McCabe J. R., Rai V. K., Thiemens M. H., Pyle D. M., Heaton T. H. E., Sloane H. J. and Fern G. R. (2006) Oxygen and sulfur isotopic composition of volcanic sulfate aerosol the point of emission. J. Geophys. Res. 111, D18205.

Oppenheimer C., Kyle P., Eisele F., Crawford J., Huey G., Tanner D., Saewung K., Mauldin L., Blake D., Beyersdorf A., Buhr M. and Davis D. (2010), Atmospheric chemistry of an Antarctic volcanic plume. J. Geophys. Res. 115, D04303, doi:10.1029/2009JD011910.

Quisefit JP, Bergametti G, Tedesco D, Pinart J, and Colin JL (1988) Origin of particulate potassium in Mt Etna emissions before and during the 1983 eruption. J. Volcanol. Geotherm. Res. 35, 111119.

Platt U. and Stutz J (2008) Differential Optical Absorption Spectroscopy: Principles and Applications. Springer-Verlag, Heidelberg, $272 \mathrm{pp}$.

Renard J.-B., Dulac F., Berthet G., Lurton T., Vignelles D., Jégou F., Tonnelier T., Thaury C., Jeannot M., Couté B., Akiki R., Mineau J.-L., Verdier N., Mallet M., Gensdarmes F., Charpentier P., Mesmin S., Duverger V., Dupont J.-C., Elias T., Crenn V., Sciare J., Giacomoni J., Gobbi M., Hamonou E., Olafsson H., Dagsson-Waldhauserova P., Camy-Peyret C., Mazel C., Décamps T., 
Piringer M., Surcin J. and Daugeron D. (2016) LOAC: a small aerosol optical counter/sizer for ground-based and balloon measurements of the size distribution and nature of atmospheric particles - Part 1: Principle of measurements and instrument evaluation. Atmos. Meas. Tech. 9, 1721-1742, doi:10.5194/amt-9-1721-2016.

Roberts T. J, Braban., C. F., Martin R. S., Oppenheimer C., Adams J. W., Cox R. A., Jones R. L. and Griffiths P. T. (2009) Modelling reactive halogen formation and ozone depletion in volcanic plumes. Chem. Geol. 263, 1, 151-163.

Roberts T. J., Braban C., Oppenheimer C., Martin R. S., Saffell J. R., Dawson D., Freshwater R. A., Griffiths, P. T. and Jones R. L. (2012) Electrochemical sensing of volcanic plumes. Chem. Geol. 332-333, 74-91.

Roberts T. J., Martin R. S. and Jourdain L. (2014a) Reactive halogen chemistry in Mt Etna's volcanic plume: the influence of total $\mathrm{Br}$, high temperature processing, aerosol loading and plume-air mixing (volcanic emissions flux). Atmos. Chem. Phys. 14, 11201-11219, doi:10.5194/acp-1411201-2014.

Roberts T. J., Jourdain L. Griffiths P. T. and Pirre M. (2014b) Re-evaluating the reactive uptake of $\mathrm{HOBr}$ in the troposphere with implications for the marine boundary layer and volcanic plumes. Atmos. Chem. Phys. 14, 11185-11199, doi:10.5194/acp-14-11185-2014.

Roberts T. J., Lurton T., Giudice G., Liuzzo M., Aiuppa A., Coltelli M., Vignelles D., Salerno G., Couté B., Chartier M., Baron R., Saffell J. R. and Scaillet B. (2017) Validation of a novel multi-gas sensor for volcanic $\mathrm{HCl}$ alongside $\mathrm{H}_{2} \mathrm{~S}$ and $\mathrm{SO}_{2}$ at $\mathrm{Mt}$ Etna. Bull. Volcanol., 79, 36, doi:10.1007/s00445-017-1114-z.

Salerno G. G., Burton M., Oppenheimer C., Caltabiano T., Randazzo D. and Bruno N. (2009) Threeyears of $\mathrm{SO}_{2}$ flux measurements of Mt. Etna using an automated UV scanner array: comparison with conventional traverses and uncertainties in flux retrieval. J. Volcanol. Geotherm. Res. 183, 76-83, doi:10/1016j.jvolgeores.2009.02.013.

Schmidt A., Carslaw K. S., Mann G. W., Rap A., Pringle K. J., Spracklen D. V., Wilson M. and Forster P. M. (2012) Importance of tropospheric volcanic aerosol for indirect radiative forcing of climate. Atmos. Chem. Phys. 12, 7321-7339.

Schumann U., Weinzierl B., Reitebuch O., Schlager H., Miniki A., Forster C., Baumann R., Saile T., Graf K., Mannstein H., Voigt C., Rahm S., Simmet R., Scheibe M., Lichtenstern M., Stock P., Rüba H., Schäuble D., Tafferner A., Rautenhaus M., Gerz T., Ziereis H., Krautstrunk M., Mallaun C., Gayet J.-F., Lieke. K., Kandler K., Ebert M., Weinbruch S., Stohl A., Gasteiger J., Groß S., Freudenthaler V., Wiegner M., Ansmann A., Tesche M., Olafsson H. and Sturm K. (2011) Airborne observations of the Eyjafjalla volcano ash cloud over Europe during air space closure in April and May 2010. Atmos. Chem. Phys. 11, 2245-2279.

Scollo S., Kahn R. A., Nelson D. L., Coltelli M., Diner D. J., Garay M. J. and Realmuto V. J. (2012) MISR observations of Etna volcanic plumes. J. Geophys. Res. 117, D06210, doi: doi:10.1029/2011JD016625. 
Seinfeld J.H. and Pandis S. N. (2006) Atmospheric Chemistry and Physics. John Wiley \& Sons, Chapter 7.

Sellitto P., di Sarra A., Corradini S., Boichu M., Herbin H., Dubuisson P., Sèze G., Meloni D., Monteleone F., Merucci L., Rusalem, J., Salerno G., Briole P. and Legras B. (2016) Synergistic use of Lagrangian dispersion modelling, satellite and surface remote sensing measurements for the investigation of volcanic plumes: the Mount Etna eruption of 25-27 October 2013. Atmos. Chem. Phys. 16, 6841-6861.

Shcherbakov V., Jourdan O., Voigt C., Gayet J.-F., Chauvigne A., Schwarzenboeck A., Minikin A., Klingebiel M., Weigel R., Borrmann S., Jurkat T., Kaufmann S., Schlage R., Gourbeyre C., Febvre G., Lapyonok T., Frey W., Molleker S. and Weinzierl B. (2016) Porous aerosol in degassing plumes of Mt. Etna and Mt. Stromboli. Atmos. Chem. Phys. 16, 11883-11897, doi:10.5194/acp-16-11883-2016, 2016.

Shinohara H., Aiuppa A., Giudice G., Gurrieri S., and Liuzzo M. (2008) Variation of $\mathrm{H}_{2} \mathrm{O} / \mathrm{CO}_{2}$ and $\mathrm{CO}_{2} / \mathrm{SO}_{2}$ ratios of volcanic gases discharged by continuous degassing of Mount Etna volcano, Italy. J. Geophys. Res. 113, B09203, doi:10.1029/2007JB005185.

Spinetti C. and Buongiorno M. F. (2007) Volcanic aerosol optical characteristics of Mt. Etna tropospheric plume retrieved by means of airborne multispectral images. J. Atmos. SolarTerr. Phys. 69, 981-994.

Surl L., Donohoue D., Aiuppa A., Bobrowski N. and von Glasow R. (2015) Quantification of the depletion of ozone in the plume of Mount Etna. Atmos. Chem. Phys. 15, 2613-2628, doi:10.5194/acp-15-2613-2015.

Tabazadeh A., Toon O. B., Clegg S. L. and Hamill P. (1997) A new parameterization of $\mathrm{H}_{2} \mathrm{SO}_{4} / \mathrm{H}_{2} \mathrm{O}$ aerosol composition: atmospheric implications. Geophys. Res. Lett. 24, 1931-1934.

Tang I. N. and Munkelwitz H. R. (1994) Water activities, densities, and refractive indices of aqueous sulfates and sodium nitrate droplets of atmospheric importance. J. Geophys. Res. Atmos. 99, 18801-18808.

Theys N., De Smedt I., Van Roozendael M., Froidevaux L., Clarisse L. and Hendrick F. (2014) First satellite detection of volcanic OClO after the eruption of Puyehue-Cordón Caulle. Geophys. Res. Lett. 41, 667-672.

Toutain J.-P., Quisefit J.-P., Briole P., Aloupogiannis P., Blanc P. and Robaye G. (1995) Mineralogy and chemistry of solid aerosols emitted from Mount Etna. Geochem. J. 29, 163-173.

Vance A., McGonigle A. J. S., Aiuppa A., Stith J. L. Turnbull K. and von Glasow R. (2010) Ozone depletion in tropospheric volcanic plumes. Geophys. Res. Lett. 37, L22802, doi:10.1029/2010GL044997.

Vignelles D., Roberts T.J., Carboni E., Ilyinskaya E., Pfeffer M., Dagsson-Waldhauserova P., Schmidt A., Berthet G., Jegou F., Renard J.-B., Ólafsson H., Bergsson B., Yeo R., Fannar Reynisson N., Grainger R.G., Galle B., Conde V., Arellano S., Lurton T., Couté B. and Duverger V. (2016) 
Balloon-borne measurement of the aerosol size distribution from an Icelandic flood basalt eruption. Earth Planet. Sci. Lett. 453, 252-259.

Vié le Sage R. (1983) Chemistry of the volcanic aerosol. In Forecasting Volcanic Events (Ed. H. Tazieff and J-C Sabroux), Elsevier, Amsterdam, 445-474.

von Glasow R., Bobrowski N. and Kern C. (2009) The effects of volcanic eruptions on atmospheric chemistry. Chem. Geol. 263, 131-42.

von Glasow R. (2010) Atmospheric chemistry in volcanic plumes. Proc. Nat. Acad. Sci. 107, 65946599.

Watson I. M. and Oppenheimer C. (2000) Particle size distributions of Mount Etna's aerosol plume constrained by Sun photometry. J. Geophys. Res., 105, 9823-9829.

Watson I. M. and Oppenheimer C. (2001) Photometric observations of Mt. Etna's different aerosol plumes., Atmos. Environ. 35, 3561-3572.

Witt M. L. I., Mather T. A., Pyle D. M., Aiuppa A., Bagnato E. and Tsanev V. I. (2008) Mercury and halogen emissions from Masaya and Telica volcanoes, Nicaragua. J. Geophys. Res. 133, B06203, doi:10.1029/2007JB005401.

Wittmer, J., Bobrowski N., Liotta M., Giuffrida, G., Calabrese S. and Platt U. (2014) Active alkaline traps to determine acidic-gas ratios in volcanic plumes: Sampling techniques and analytical methods. Geochem. Geophys. Geosyst. 15, 2797-2820, doi:10.1002/2013GC005133. 


\section{Figures}

Figure 1. Schematic showing role of aerosol in volcanic plume halogen chemistry that converts emitted $\mathrm{HBr}$ and $\mathrm{HCl}$ into reactive halogens $\mathrm{BrO}$ and $\mathrm{OClO}$. Chemical cycles at ambient temperature are 'kick-started' by the high-temperature production of radicals and sulfate aerosol precursors.

Figure 2. Map of Etna volcano summit, showing the measurement track that sampled the three summit crater emissions before descending on the flank, as well as the location of near-downwind grounding plume ( $\sim 1.5 \mathrm{~km}$ from summit) sampled on 02 and 04 October, 2012.

Figure 3. (a) Time-series of $\mathrm{SO}_{2}$ mixing ratio and (b) total aerosol volume density measured by MultiGas and LOAC OPC on 02 October 2012.

Figure 4. Selected 'Vweak' time-period: (a) time-series of $\mathrm{SO}_{2}$ mixing ratio and (b) total aerosol volume density measured by Multi-Gas and LOAC OPC. See Figure 3 for Multi-Gas sensor legend.

Figure 5. Selected 'DW1' and 'DW2' time-period: (a) time-series of $\mathrm{SO}_{2}$ mixing ratio and (b) total aerosol volume density measured by Multi-Gas and LOAC OPC. See Figure 3 for Multi-Gas sensor legend.

Figure 6. Scatter plot of total aerosol volume density and $\mathrm{SO}_{2}$ mixing ratio during four selected timeperiods (Vweak, Flank, DW1, DW2), measured at $0.1 \mathrm{~Hz}$ by LOAC OPC and Multi-Gas, respectively. Also shown is the linear regression on ' $V$ weak' dataset, that has gradient $64.8 \mu^{3} \mathrm{~cm}^{-3}$ per ppmv $\mathrm{SO}_{2}$ and intercept $2.2 \mu \mathrm{m}^{3} \mathrm{~cm}^{-3}$.

Figure 7. Particle number density versus $\mathrm{SO}_{2}$ mixing ratio shown for three aerosol size-bins: 3-5, 1-3 and 0.9-1.1 $\mu \mathrm{m}$ diameter (upper, middle, lower, respectively). Both 'Vweak' and 'Flank' datasets are shown in each panel.

Figure 8. Volumic aerosol size distribution for the (a) 'Flank' and (b) 'Vweak' datasets. Aerosol $\mathrm{dV} / \mathrm{dLogD}$ data has been normalized for $1 \mathrm{ppmv} \mathrm{SO}_{2}$ and is coloured according to plume strength denoted by co-measured $\mathrm{SO}_{2}$.

Figure 9. a: volumic aerosol size distribution for the 'Vweak' dataset where aerosol dV/dLogD data has been normalized for 1 ppmv $\mathrm{SO}_{2}$ and is coloured according to plume strength denoted by comeasured $\mathrm{SO}_{2}$. b: instrument model predicts a 'measured' size distribution for a given input distribution. Both plots exhibit enhancements in the 1-2 $\mu \mathrm{m}$ range.

Figure 10. Aerosol size distribution for selected data (when $\mathrm{SO}_{2}=0.3-0.4 \mathrm{ppmv}$ ) from the Vweak time-period, shown as (a) number, (b) surface area and (c) volumic distributions. The $d[] / d L o g D$ datasets have been normalized to 1 ppmv $\mathrm{SO}_{2}$ and are shown with logarithmic y-axis. Each $10 \mathrm{~s}$ size distribution measurement is shown (blue lines, connecting the simultaneous observations in each size-bin) as well as time-averaged mean values for each size-bin (black dots) with standard error in the mean. The fitted multi-modal lognormal distribution exhibits peaks corresponding to three modes.

Figure 11. Aerosol size distributions for selected data (when $\mathrm{SO}_{2}=0.3-0.4 \mathrm{ppmv}$ ) from the Vweak time-period, shown as (a) number, (b) surface area and (c) volumic distributions. The $d[] / d L o g D$ 
datasets have been normalized to $1 \mathrm{ppmv} \mathrm{SO}_{2}$ and are shown with linear $\mathrm{y}$-axis. Each $10 \mathrm{~s}$ size distribution measurement is shown (blue lines, connecting the simultaneous observations in each size-bin) as well as time-averaged mean values for each size-bin (black dots) with standard error in the mean. The fitted multi-modal lognormal distribution exhibits peaks corresponding to three modes.

Figure 12. Primary volcanic aerosol from Mt Etna from this work shown alongside representative atmospheric aerosols (urban, rural, desert dust storm, marine, polar) from Jaenicke (1993). The lognormal distributions are shown as $\mathrm{dN} / \mathrm{dLog} 10(\mathrm{R})$ versus Radius. The volcanic aerosol distribution shown is for primary aerosol at a plume of strength 1 ppmv $\mathrm{SO}_{2}$ on Mt Etna flank. See Table 5 for details. Note that our volcanic particle size distribution misses the fraction $<0.1 \mu \mathrm{m}$ due to instrumental limitations.

Figure 13. Aerosol size distributions calculated across a range of relative humidity, based on the selected data of Figures 9 and 10 and a hygroscopic aerosol growth model (see Section 3.5 and Appendix A3 for details). The size distributions are shown as (a) number, (b) surface area and (c) volumic distributions.

Figure 14. (a) Total surface area and (b) total volume (per ppmv $\mathrm{SO}_{2}$ or per mole sulfate) calculated across a range of relative humidity, based on the selected data of Figures 9 and 10 and a hygroscopic aerosol growth model. The underlying distributions are presented in Figure 12.

Figure 15. Simulated downwind plume chemical evolution according to the PlumeChem model. (a) $\mathrm{BrO}$, (b) OClO and (c) ozone loss are predicted relative to $\mathrm{SO}_{2}$ as a plume tracer, and compared to reported observations. The trend in ozone depletion observed by in-situ measurelents of Surl et al. (2015) is shown as a thick yellow line Observations of $\mathrm{BrO} / \mathrm{SO}_{2}$ and $\mathrm{OClO} / \mathrm{SO}_{2}$ by Gliß et al. (2015) are shown in dark green (with low $\mathrm{OClO} / \mathrm{SO}_{2}$ near-to-source confirmed by measurements below the detection limit shown in light green). Model runs are presented for 10, 50 and $90 \%$ ambient relative humidity, and at background ozone mixing ratios of 30,60 and 100 ppbv.Figure 16. Plume (a) $\mathrm{SO}_{2}$, (b) $\mathrm{BrO} / \mathrm{SO}_{2}$, (c) ozone depletion and (d) $\mathrm{OClO} / \mathrm{SO}_{2}$ simulated downwind and across-plume by the PlumeChem model assuming molar $\mathrm{HBr} / \mathrm{SO}_{2}=4.810^{-4}$.

Figure 17. Plume (a) $\mathrm{SO}_{2}$, (b) $\mathrm{BrO} / \mathrm{SO}_{2}$, (c) ozone depletion, and (d) $\mathrm{OClO} / \mathrm{SO}_{2}$ simulated downwind and across-plume by the PlumeChem model assuming molar $\mathrm{HBr} / \mathrm{SO}_{2}=7.4 \times 10^{-4}$. Note change in scale for $\mathrm{BrO} / \mathrm{SO}_{2}$ compared to Figure 16. 


\section{Low-T Plume Multi-phase Chemistry}

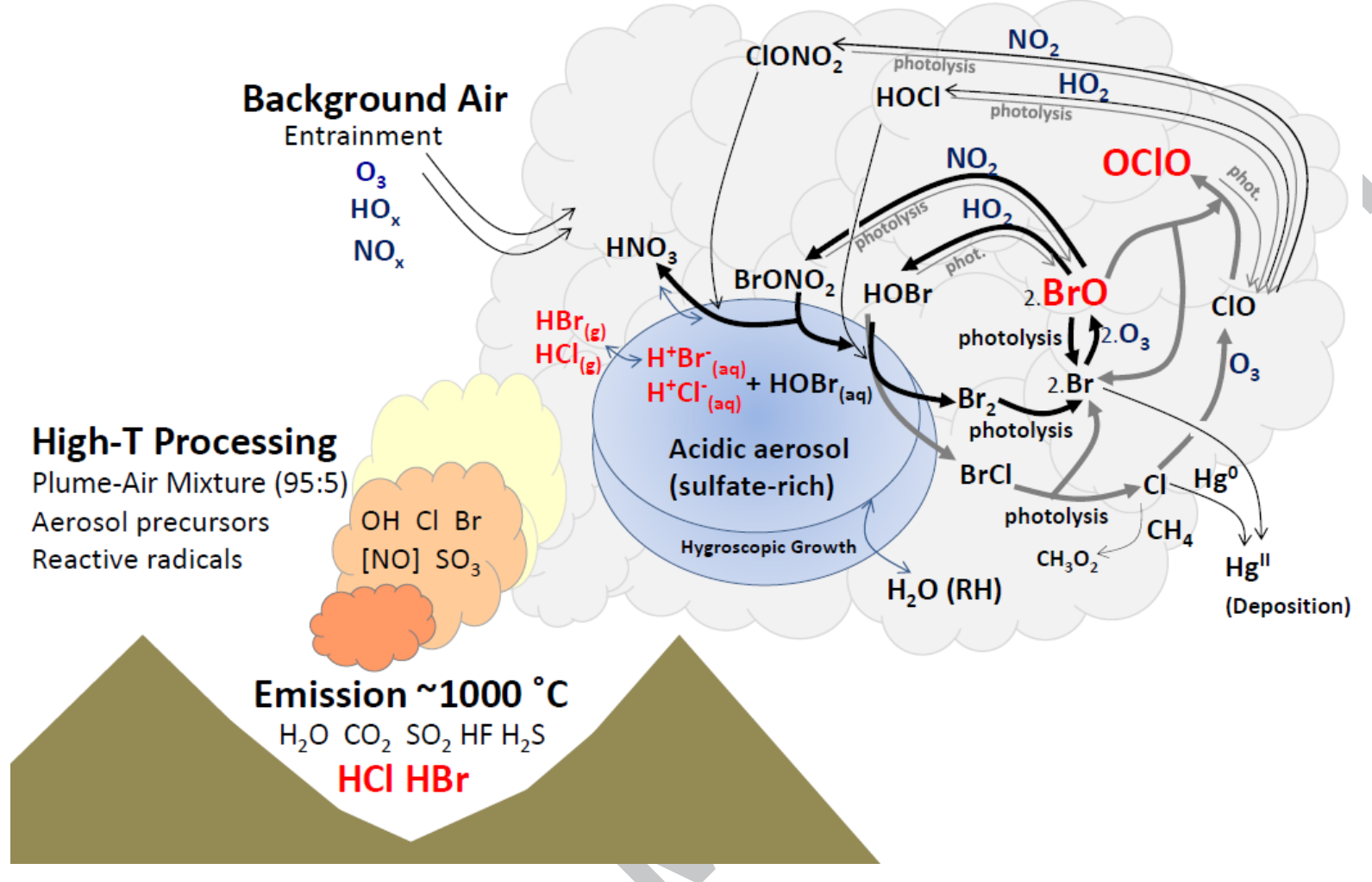

Figure 1 


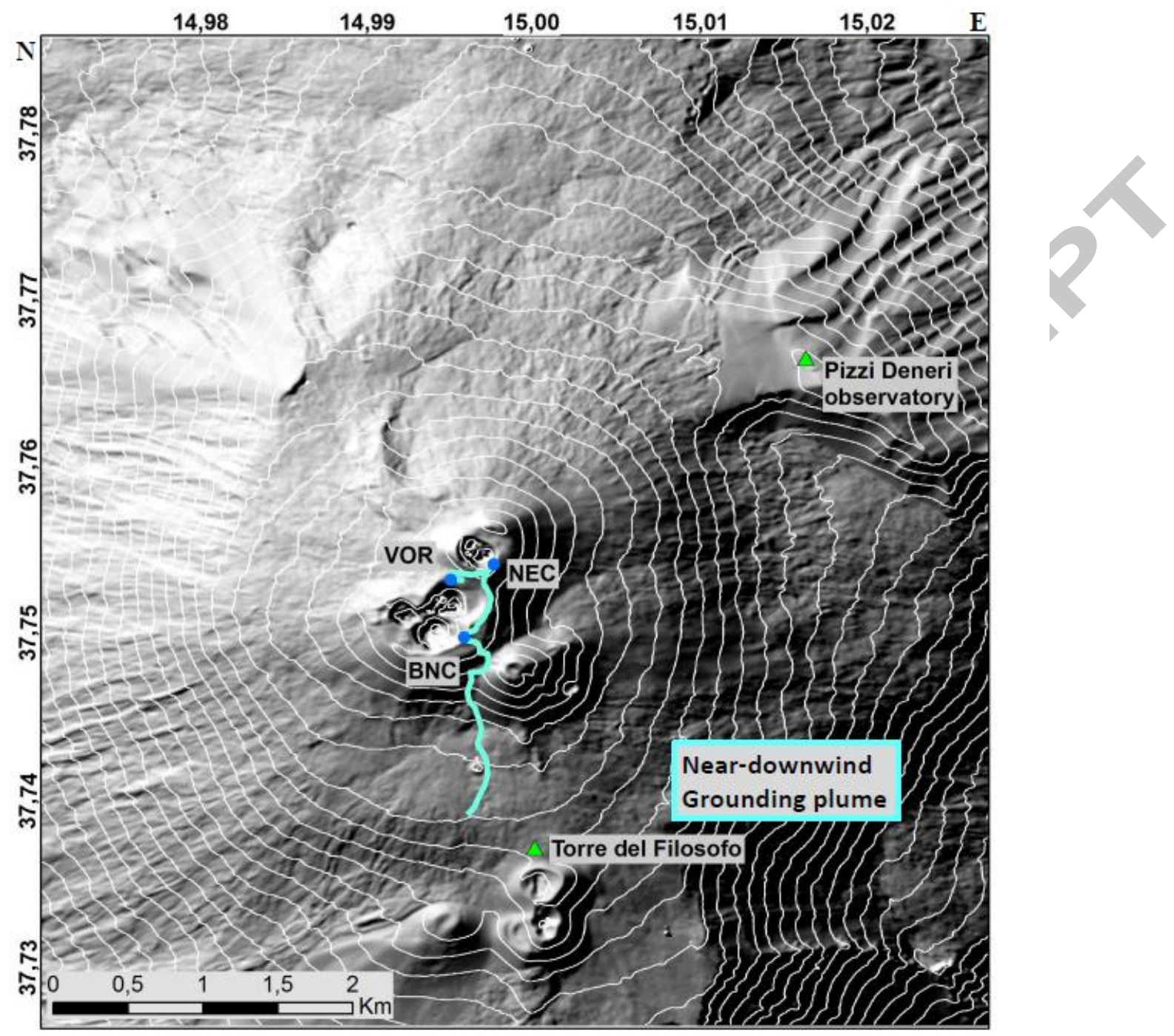

Figure 2

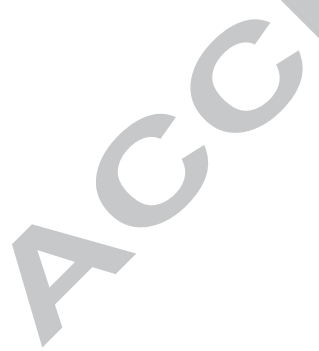




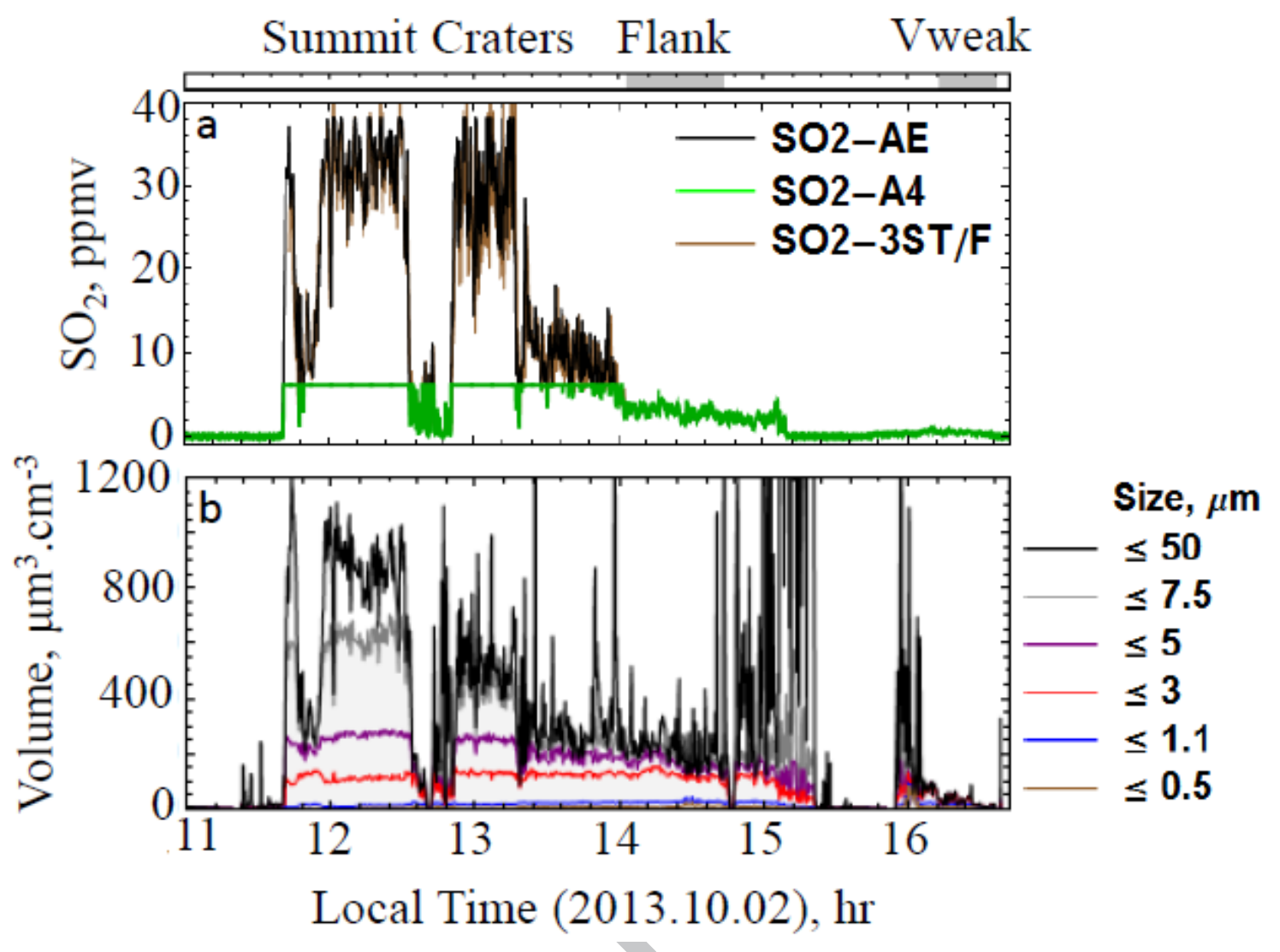

Figure 3 


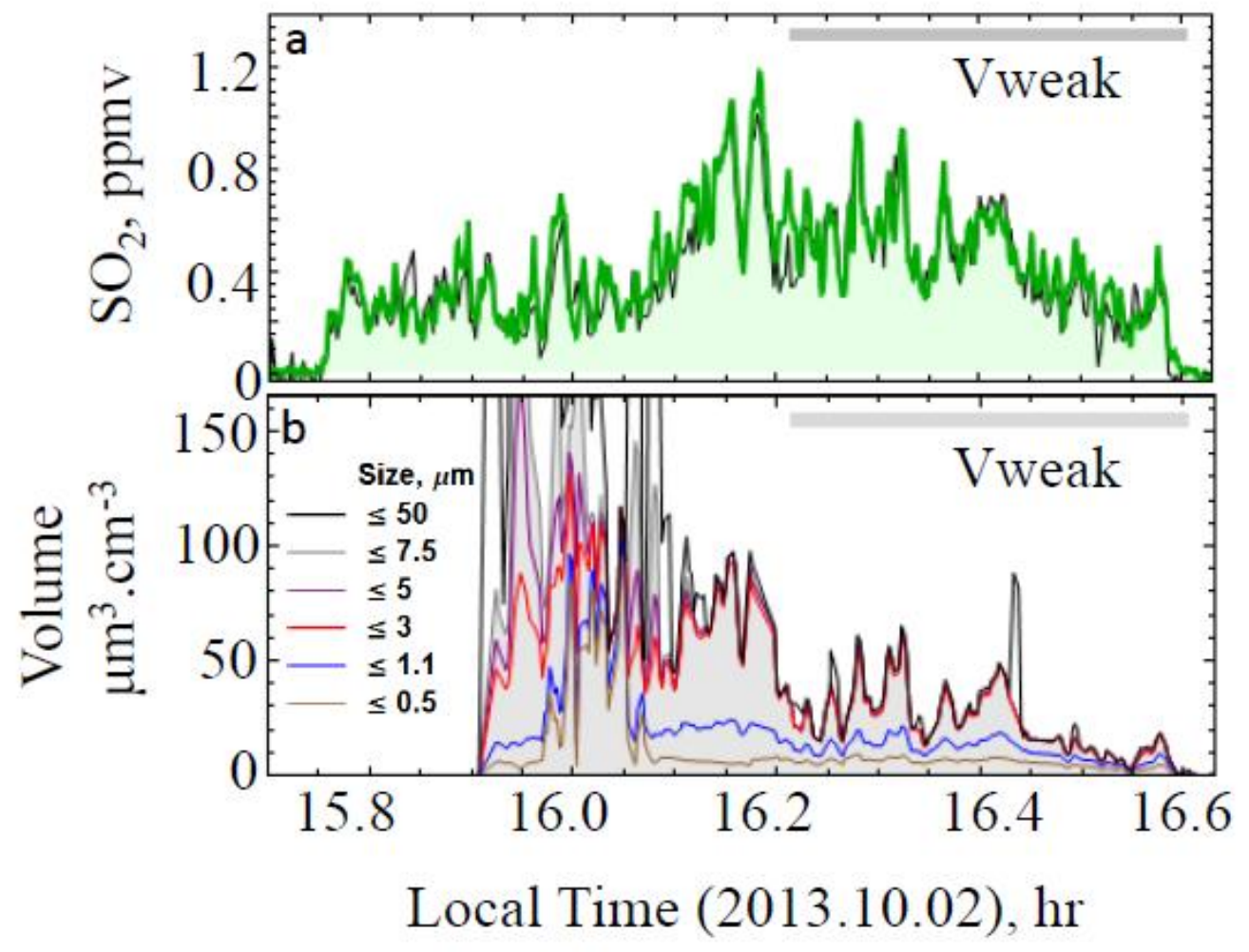

Figure 4 

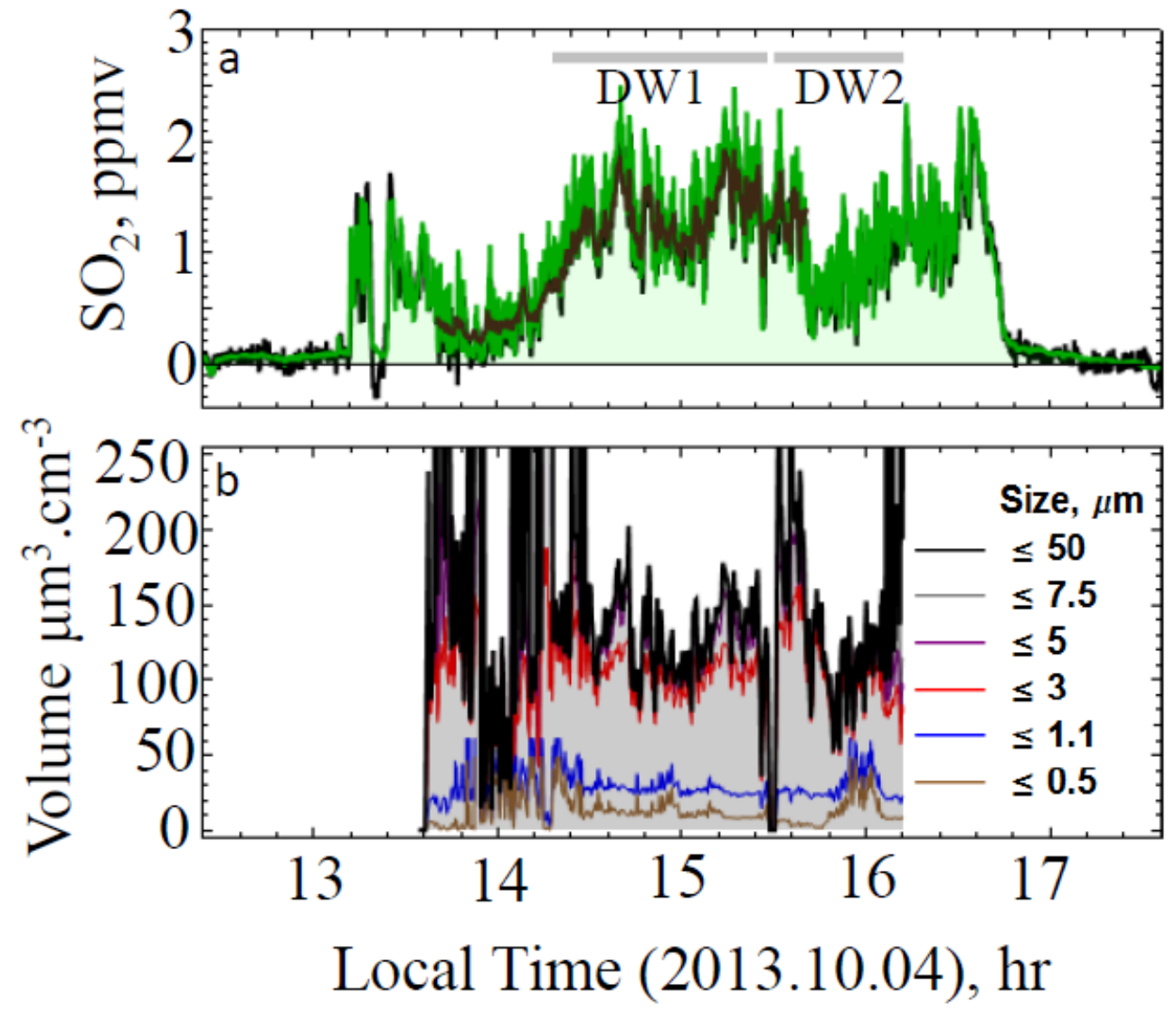

Figure 5 


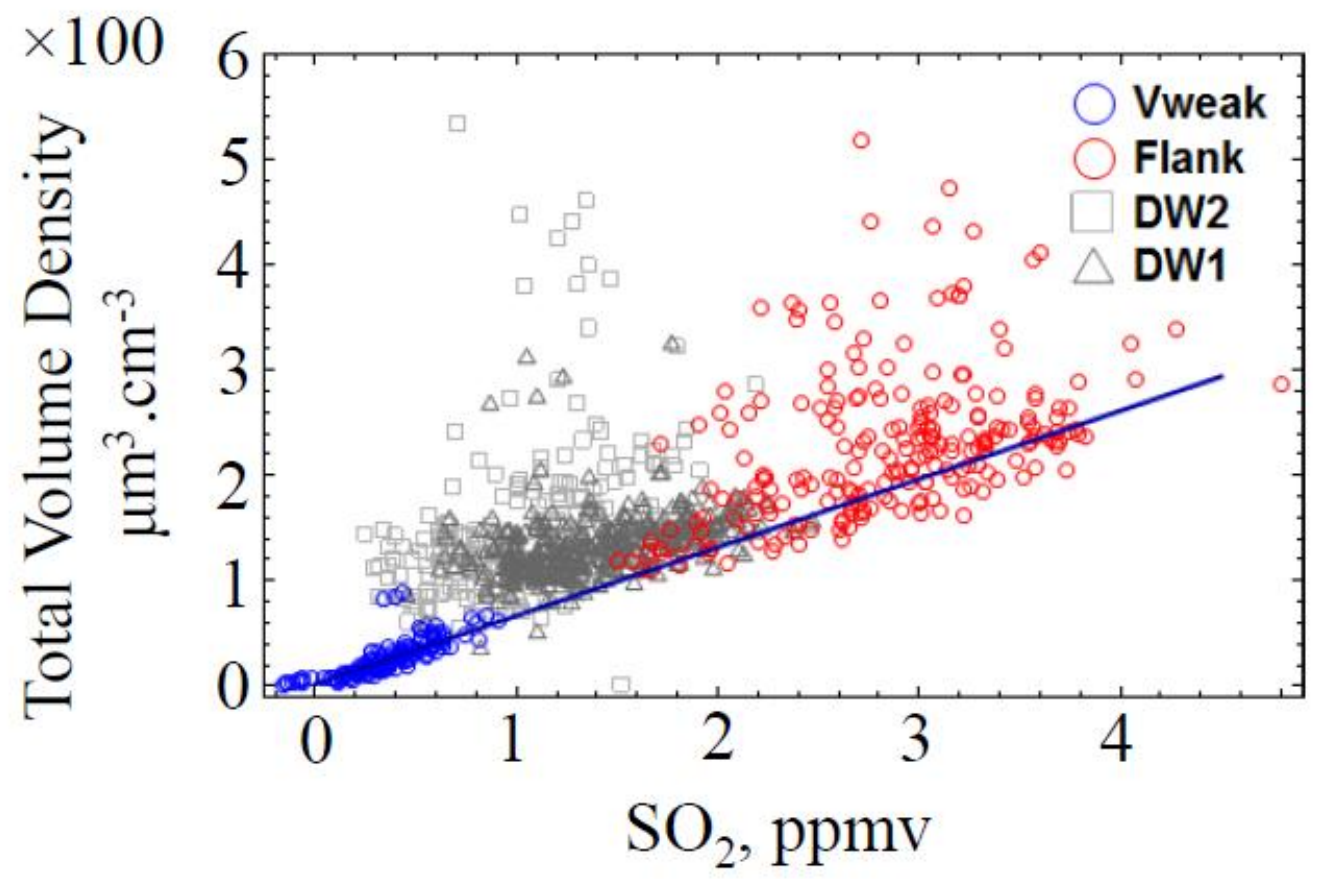

Figure 6 

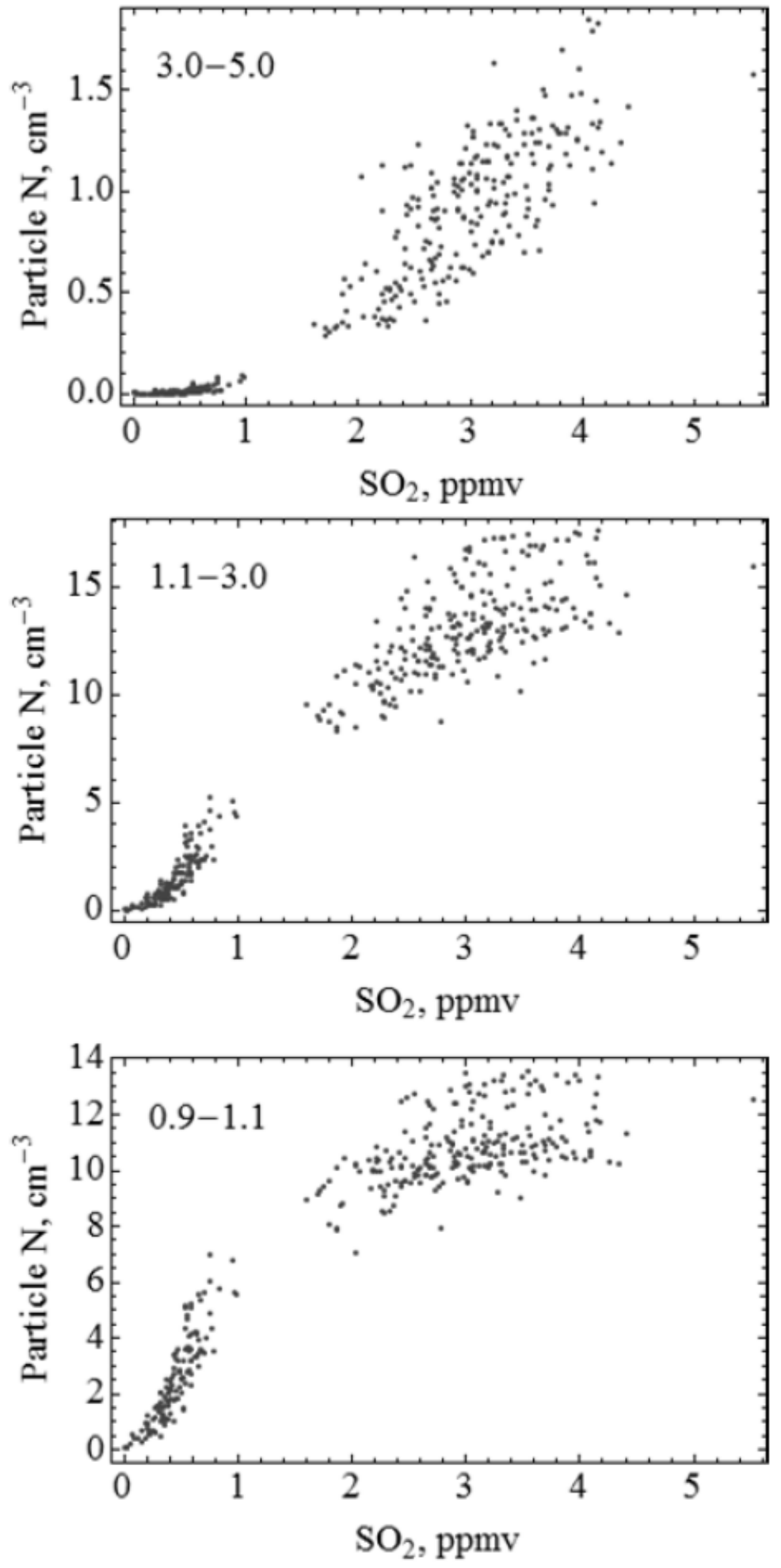

Figure 7 


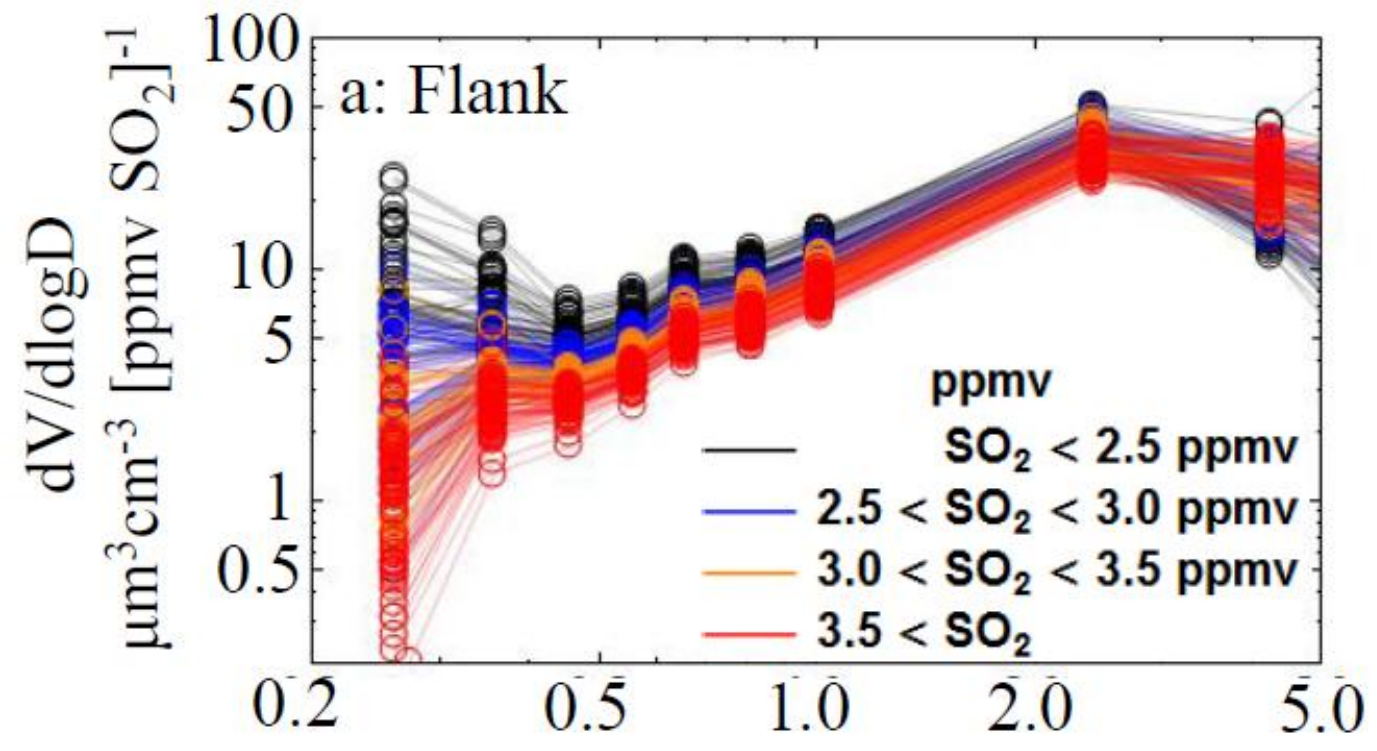

Diameter, $\mu \mathrm{m}$

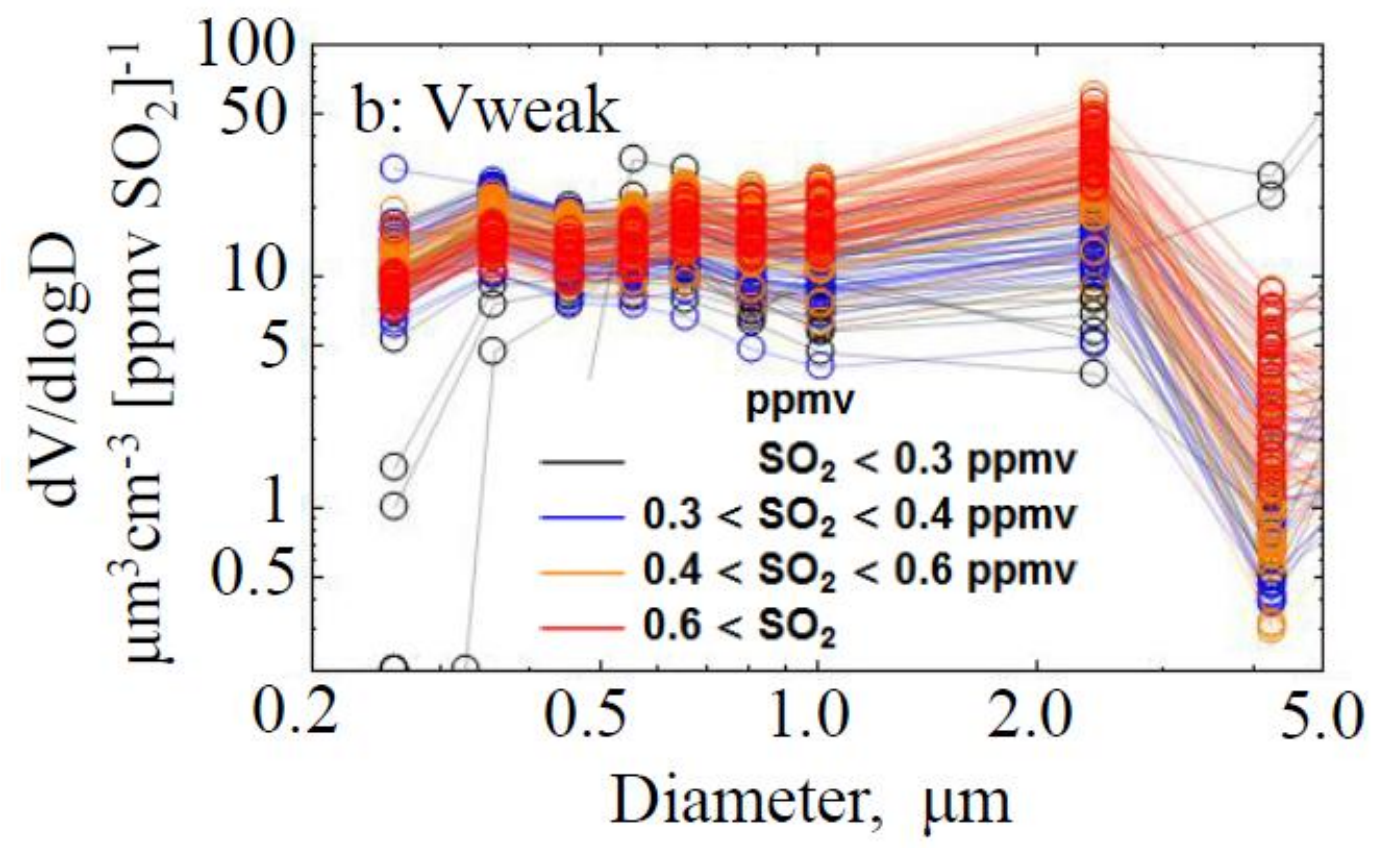

Figure 8 

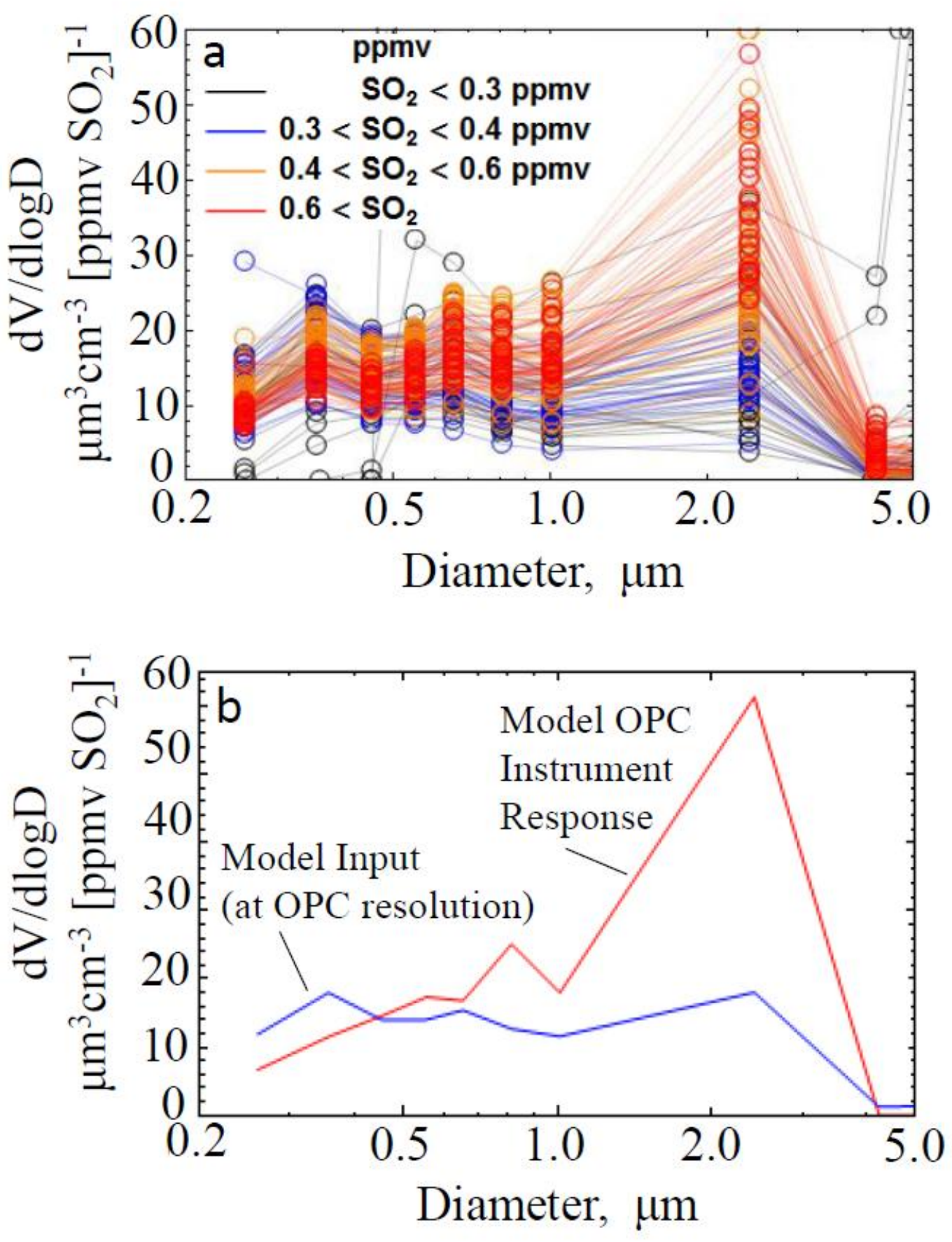

Figure 9 

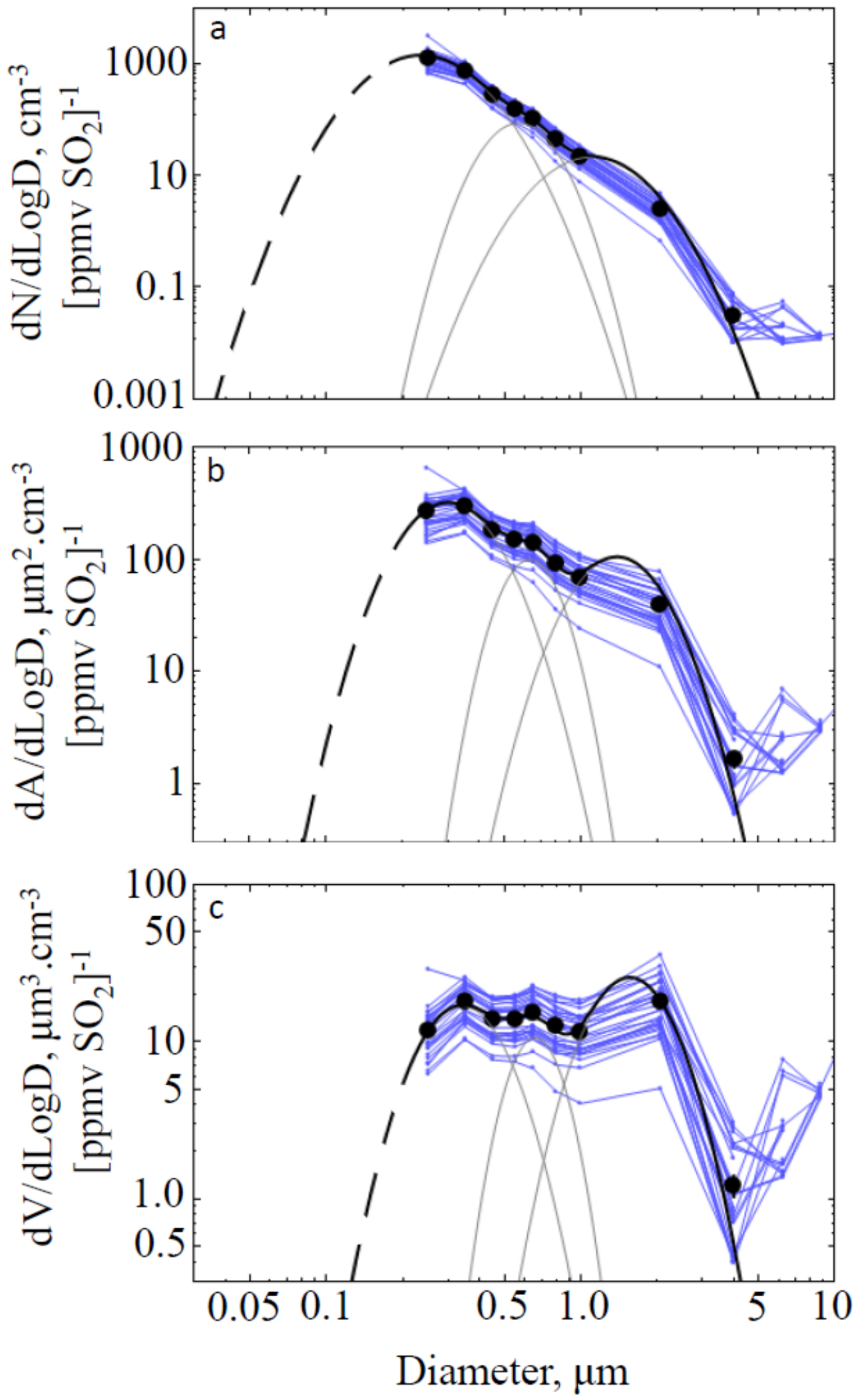

Figure 10 

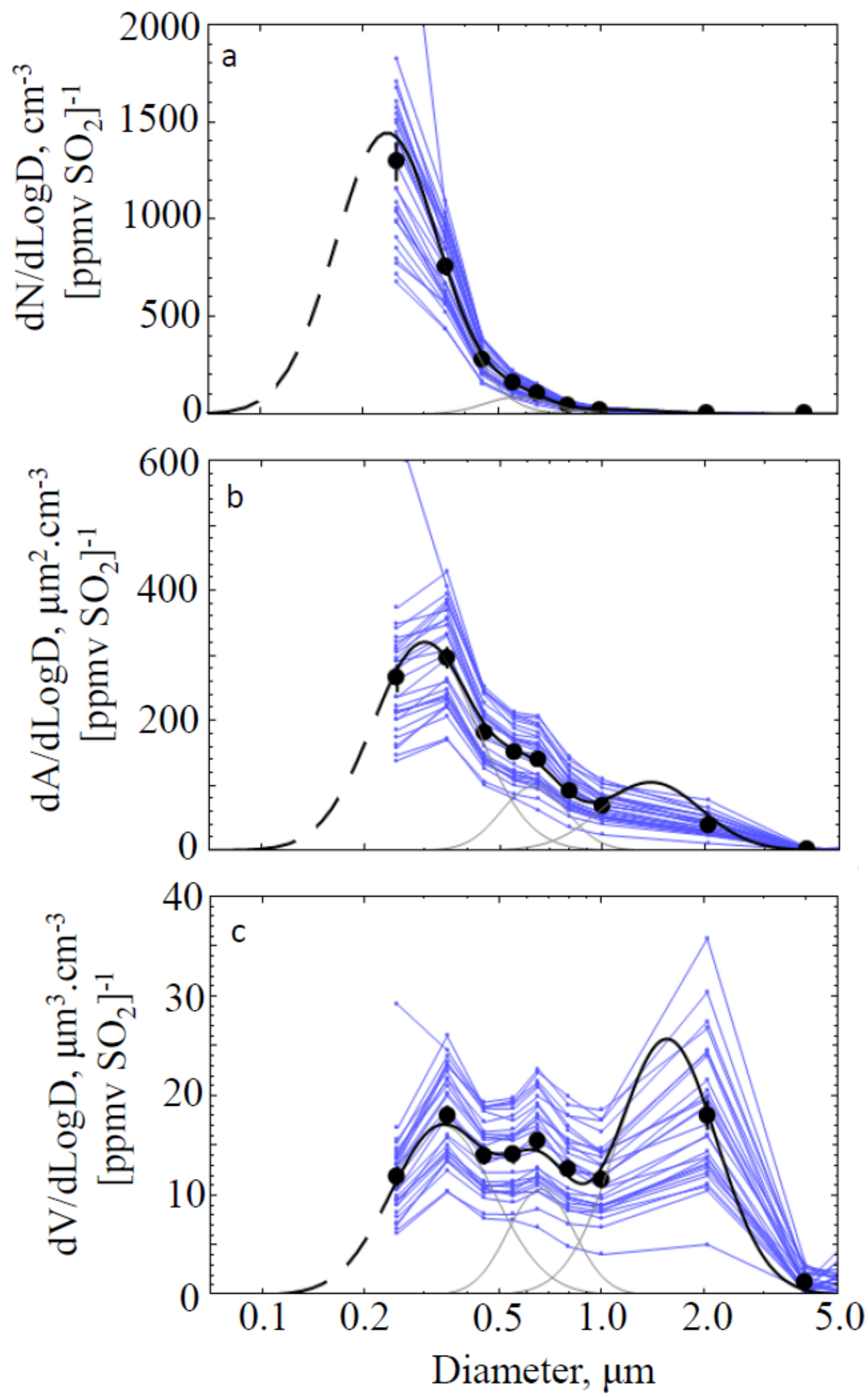

Figure 11 


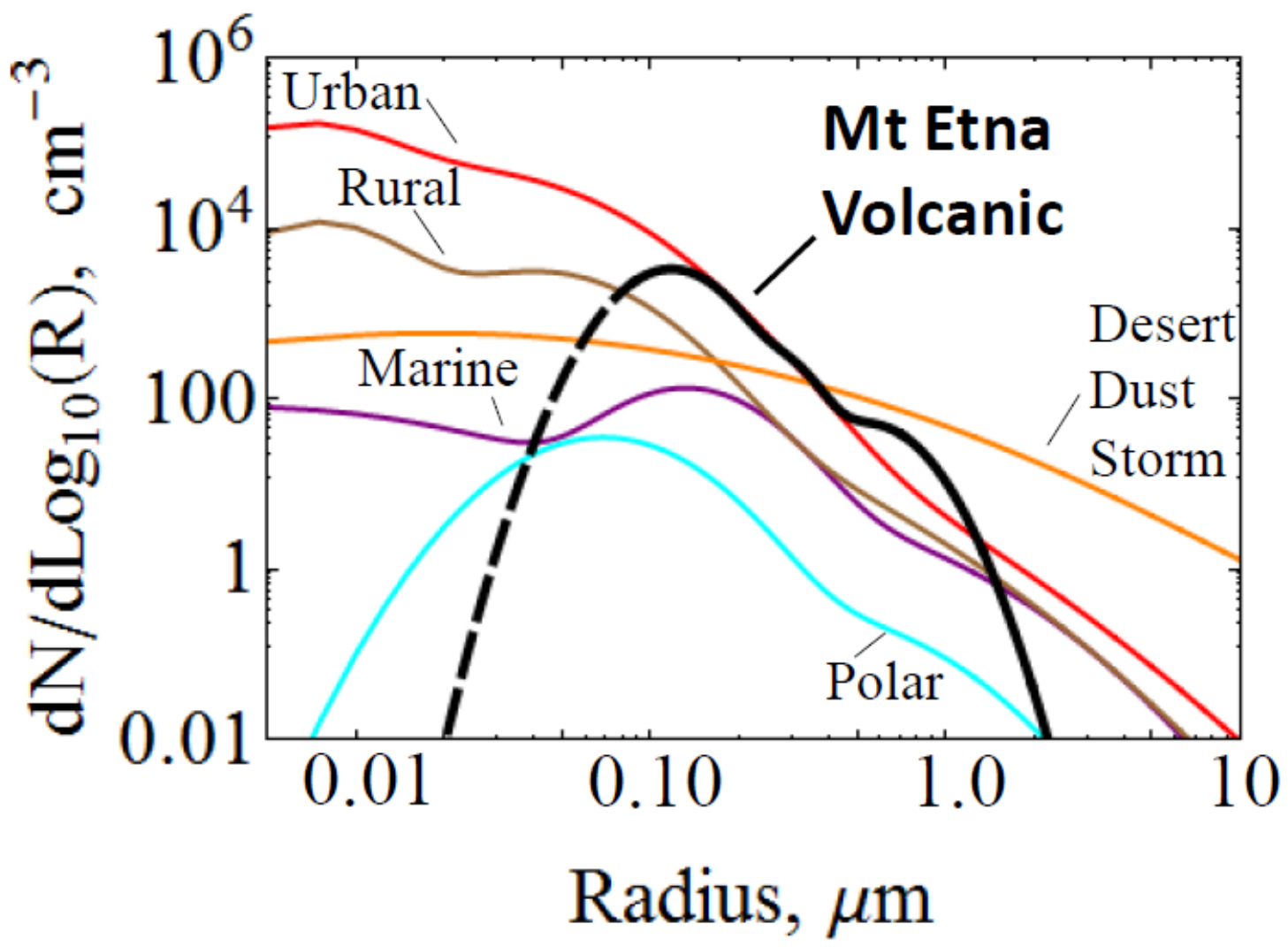

Figure 12 

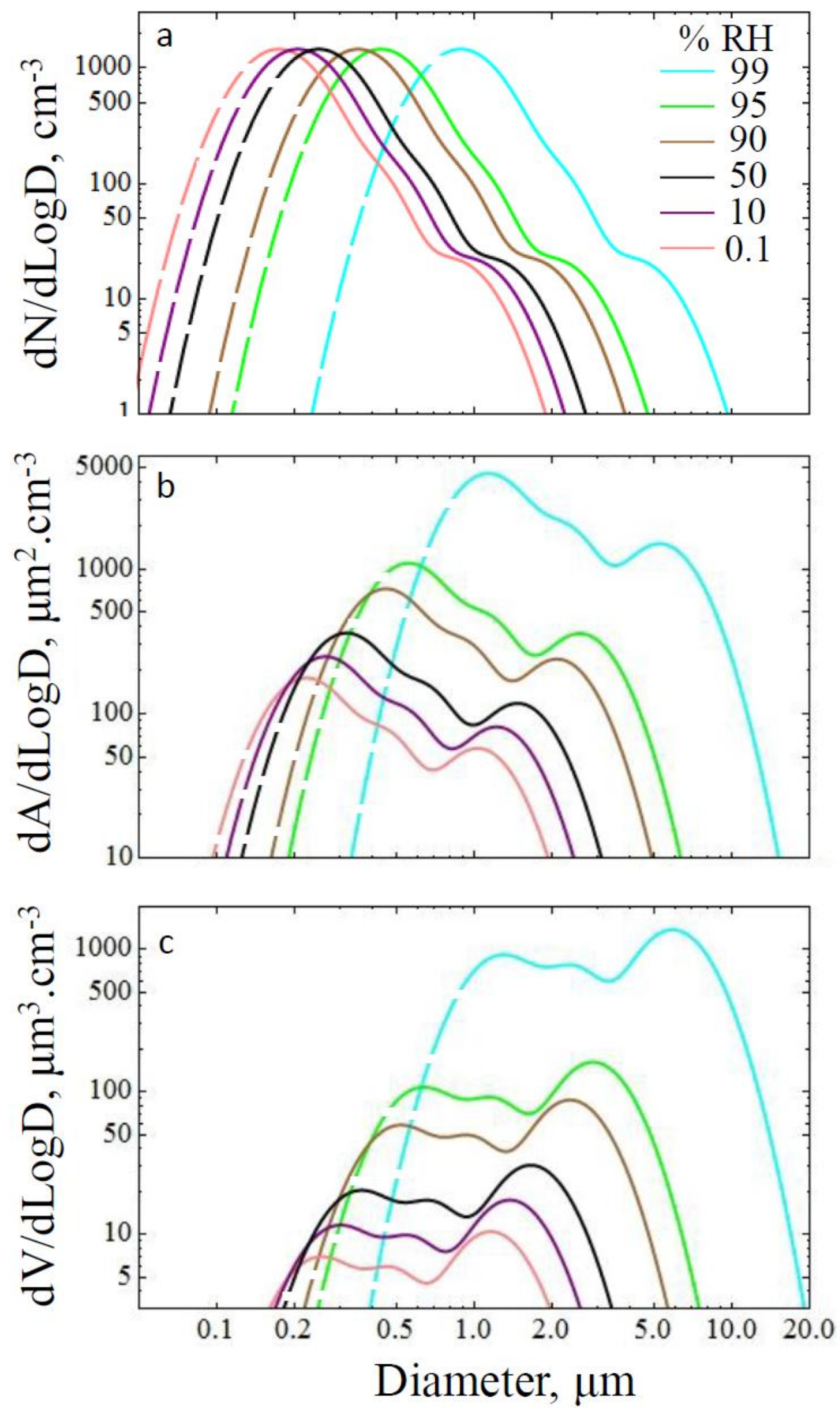

Figure 13 


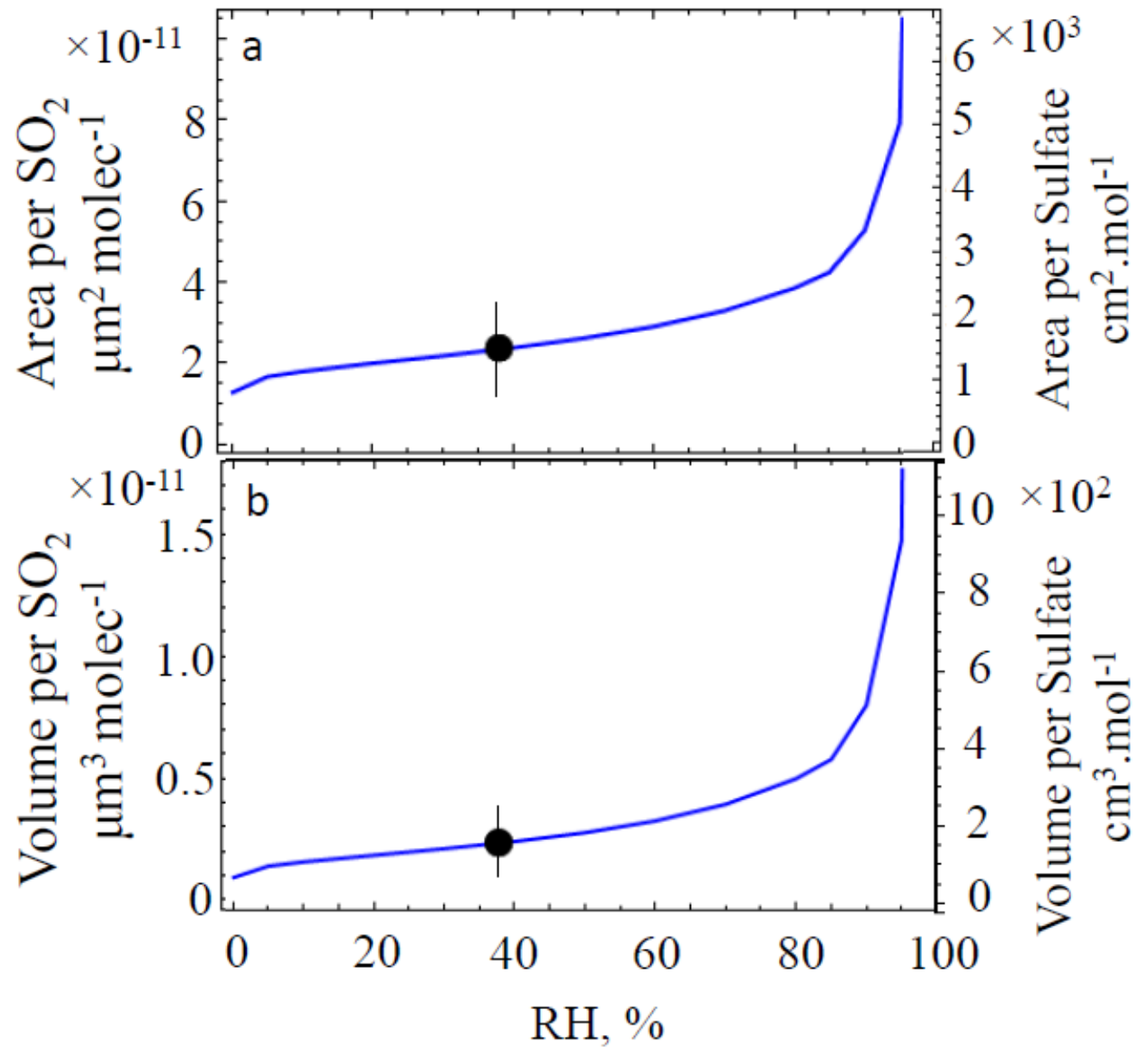

Figure 14 

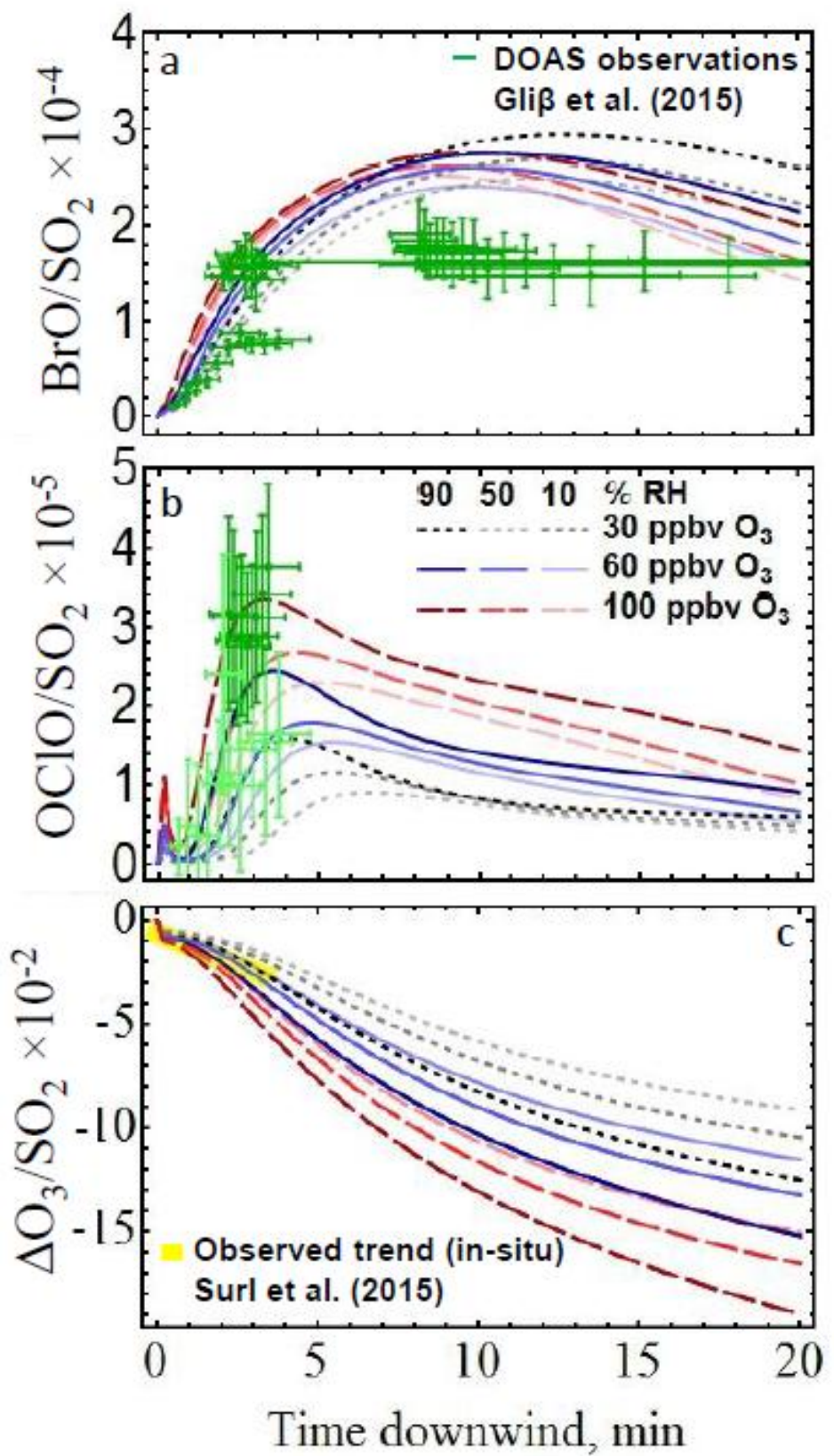

Figure 15 

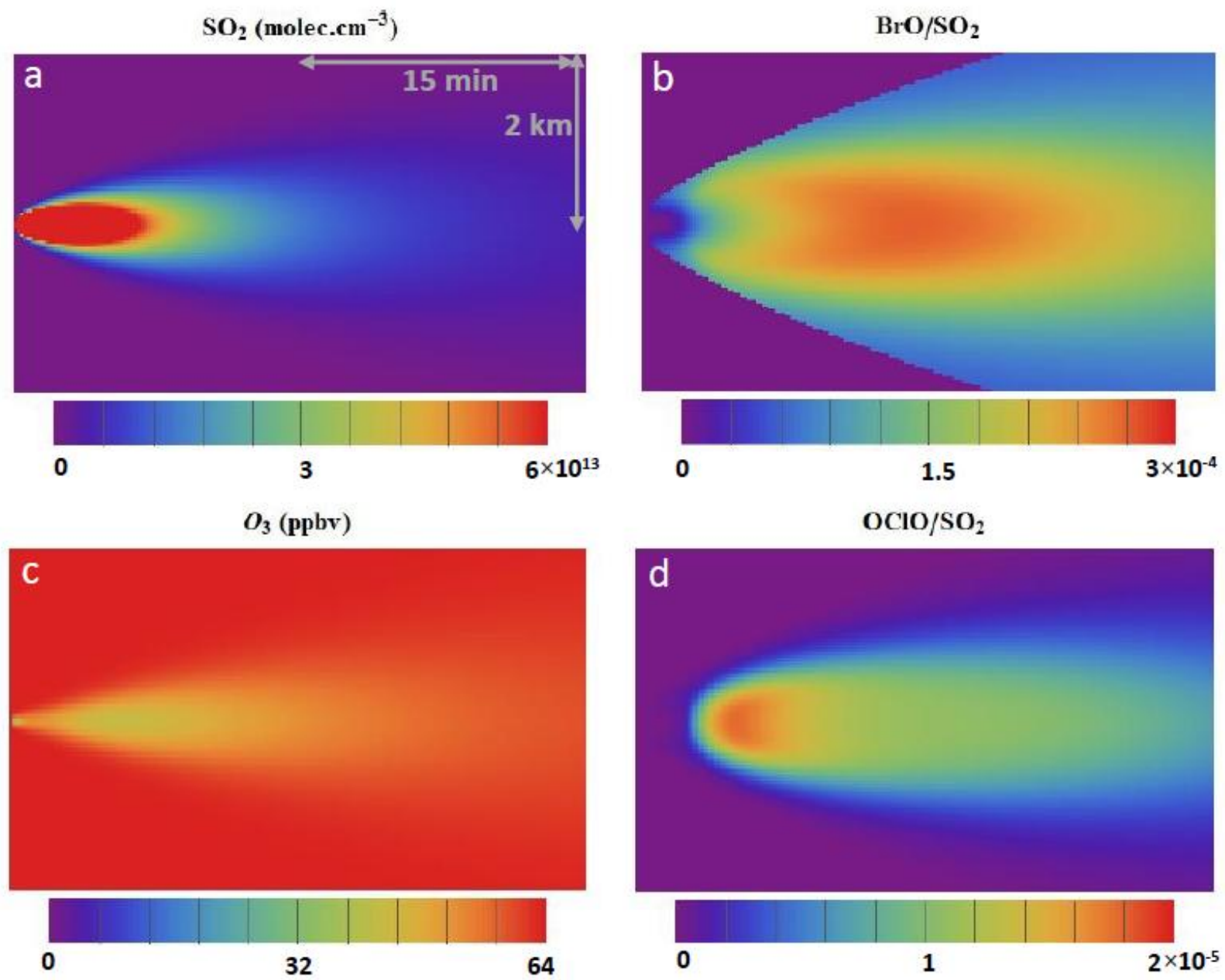

Figure 16 

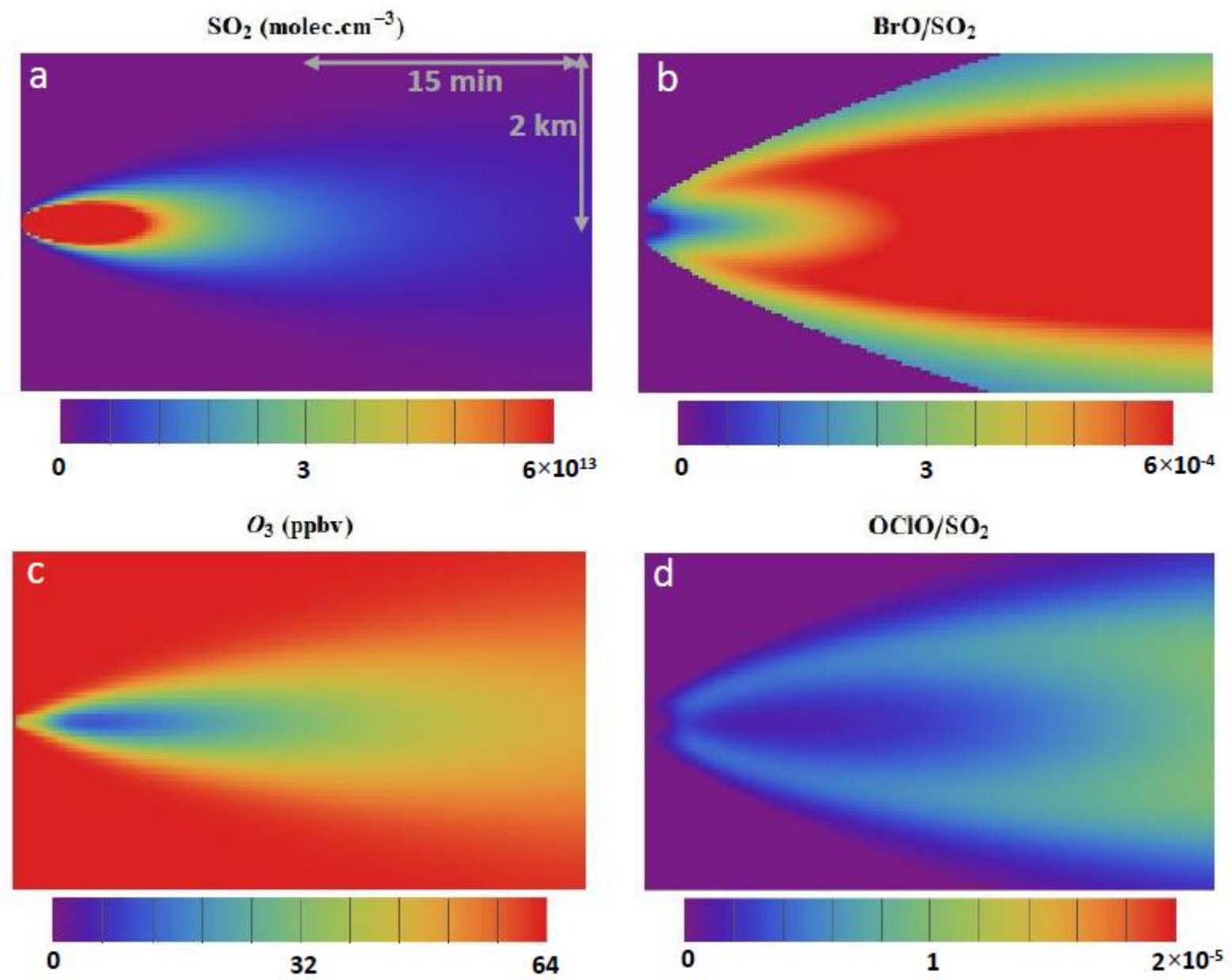

Figure 17 
Table 1. Remote sensing observations of Mt Etna plume aerosol.

\begin{tabular}{|c|c|c|c|c|}
\hline Remote Sensing Study & Methodology & Particle Size & Particle Flux & Particle Composition \\
\hline $\begin{array}{l}\text { Watson and } \\
\text { Oppenheimer } \\
2000\end{array}$ & $\begin{array}{l}\text { Sun-photometer (near source plume) } \\
\text { Range: } 0.1 \text { to } 4 \mu \mathrm{m} \text { radius }\end{array}$ & $\begin{array}{l}\text { Tri-modal distributions with minima at } 0.5 \\
\text { and } 1.5 \mu \mathrm{m} \text { radius. Volume and Area } \\
\text { distribution maxima lie beyond measurement } \\
\text { range (at both large and small sizes) } \\
\text { Effective radii (for observed range): } 0.83 \mu \mathrm{m}\end{array}$ & $\begin{array}{l}4.5-8 \mathrm{~kg} \mathrm{~s}^{-1} \text { (over measurement } \\
\text { range only i.e. lower limit. } \\
\text { Calculated using typical plume } \\
\text { width, gas flux, assumed } \\
\mathrm{H}_{2} \mathrm{SO}_{4 \text { (aa) }} / \text { water densities) }\end{array}$ & $\begin{array}{l}\text { Not characterised but } \\
\text { Sulfate/water assumed } \\
\text { for small/large particles }\end{array}$ \\
\hline $\begin{array}{l}\text { Watson and } \\
\text { Oppenheimer } \\
2001\end{array}$ & $\begin{array}{l}\text { Sun-photometer(near source plume) } \\
\text { Range: } 0.1 \text { to } 4 \mu \mathrm{m} \text { radius }\end{array}$ & $\begin{array}{l}\text { Bi-/uni-modal distributions. Volume and Area } \\
\text { distribution maxima lie beyond measurement } \\
\text { range (at both large and small sizes) } \\
\text { Effective radii: } 1.5 \text { (ash-rich), } 0.7 \text { (no ash) } \mu \mathrm{m}\end{array}$ & - & - \\
\hline $\begin{array}{l}\text { Spinetti and } \\
\text { Buongiorno, } 2007\end{array}$ & $\begin{array}{l}\text { Airborne multispectral images } \\
\text { (eruption and quiescent degassing) }\end{array}$ & $\begin{array}{l}\text { Explosive phase shows larger particles whilst } \\
\text { quiescent phase dominated by particles with } \\
\sim 1 \mu \mathrm{m} \text { effective radius. }\end{array}$ & & - \\
\hline Scollo et al., 2012 & $\begin{array}{l}\text { MISR (Multiangle Imaging } \\
\text { SpectroRadiometer) satellite } \\
\text { instrument (eruption events) }\end{array}$ & $\begin{array}{l}\text { Large and fine particles depending on } \\
\text { volcanic activity }\end{array}$ & & $\begin{array}{l}\text { Ash-dominated particles } \\
\text { larger than sulfate/water }\end{array}$ \\
\hline $\begin{array}{l}\text { Sellitto et al. } \\
2016\end{array}$ & $\begin{array}{l}\text { Sun-photometer/CIMEL at Lampedusa } \\
\text { (transported, aged eruption plume) } \\
\text { Range } 0.06 \text { to } 10 \mu \mathrm{m} \text { diameter. } \\
\text { Brewer Dobson } \mathrm{MK} \text { III for column } \mathrm{SO}_{2}\end{array}$ & $\begin{array}{l}\text { Bi-modal distributions with volume maxima at } \\
\text { radii around } 4 \mu \mathrm{m} \text { and } 0.1-0.2 \mu \mathrm{m} \text {. } \\
\mathrm{SO}_{2} \text { close to detection limit, possible } \\
\text { enhancements of } 1-2 \mathrm{DU} \text {. }\end{array}$ & - & $\begin{array}{l}\text { Large mode be likely ash, } \\
\text { fine mode sulfate }\end{array}$ \\
\hline
\end{tabular}


Table 2. In-situ observations of Mt Etna plume aerosol, by time-averaged sampling and real-time techniques.

\begin{tabular}{|c|c|c|c|c|}
\hline In-situ Study & Methodology & Particle Size & Particle Flux & Particle Composition \\
\hline Vié le Sage et al. 1983 & Cascade Impactor (Summit) & Sub-micron to supra-micron sizes & - & 40 elements detected \\
\hline Quisefit et al. 1988 & Filter samplers (near-source, vents) & - & - & Particulate potassium \\
\hline $\begin{array}{l}\text { Ammann and } \\
\text { Burtscher 1993, } \\
\text { Ammann et al. } 1993 \\
\end{array}$ & $\begin{array}{l}\text { Photoelectric charging of particles } \\
\text { and TEM for fine particle detection }\end{array}$ & Ultrafine $(\mathrm{nm})$ particles dominate number & - & $\begin{array}{l}\text { Photoelectric activity related } \\
\text { to Cu content in } \mathrm{nm} \text { particles }\end{array}$ \\
\hline $\begin{array}{l}\text { Toutain et al. } \\
1995\end{array}$ & Filter samplers (near-source, vents) & - & - & $\begin{array}{l}\mathrm{Na}, \mathrm{Al}, \mathrm{Si}, \mathrm{S}, \mathrm{Cl} \mathrm{K}, \mathrm{Ca}, \mathrm{Ti} F e, \\
\mathrm{Mn}, \mathrm{Cu}, \mathrm{Zn}\end{array}$ \\
\hline $\begin{array}{l}\text { Allen et al. } \\
2006\end{array}$ & $\begin{array}{l}\text { OPC (GRIMM } 1.108,1 \text { min averaged) } \\
\text { (summit \& near-source plume) } \\
\text { Range: } 0.3 \text { to } 20 \mu \mathrm{m} \text { diameter } \\
\text { Concurrent column } \mathrm{SO}_{2} \text { by DOAS. } \\
\text { Filter-pack sampling: Coarse }>0.35 \\
\text { and fine }<0.35 \mu \mathrm{m} \text { diameter }\end{array}$ & $\begin{array}{l}\text { Tri-modal number distributions with minima } \\
\text { at } \sim 1 \text { and } 3-4 \mu \mathrm{m} \text {. NEC (ash-rich) has more } \\
\text { supramicron particles than VOR/BN } \\
\text { (quiescently degassing). Area and Volume } \\
\text { distributions not reported. }\end{array}$ & - & $\begin{array}{l}\text { Sulfate-rich. Other ions } \\
\text { include } \mathrm{F}^{-}, \mathrm{Cl}^{-}, \mathrm{NO}_{3}^{-}, \mathrm{Na}^{+}, \mathrm{NH}_{4}^{+}, \\
\mathrm{K}^{+}, \mathrm{Mg}^{2+}, \mathrm{Ca}^{2+}, \mathrm{H}^{+} \text {. Ash-rich } \\
\mathrm{NEC} \text { had greater mineral ion } \\
\text { content. Sulfate mostly in } \\
\text { coarse mode at NEC, fine } \\
\text { mode at VOR/BN. }\end{array}$ \\
\hline $\begin{array}{l}\text { Martin et al.. } \\
2008\end{array}$ & $\begin{array}{l}\text { Filter packs and cascade impactor: } \\
\text { (summit } \& \text { near-source plume) } \\
\text { Range } \sim 0.05-18 \mu \mathrm{m} \text { diameter } \\
\text { Thermal precipitator (nm particles) } \\
\text { Range: } 4-40 \mathrm{~nm}\end{array}$ & $\begin{array}{l}\text { Sulphate ions at VOR/NEC: mono/bi-modal } \\
\text { with maxima at } 1 \mu \mathrm{m} \text { (and also } 8 \mu \mathrm{m} \text { for } \mathrm{NEC} \text { ), } \\
\text { size uncertainty due to flow rate variability. } \\
\text { Silica: mono-modal with maximum } \sim 1.4 \mu \mathrm{m} \\
\text { by number distribution ( } \sim 4 \mathrm{~m} \text { by volume). } \\
\text { Elemental Sulfur and Sulfide: mono-modal } \\
\text { with maximum } \sim 1 \mu \mathrm{m}\end{array}$ & $\begin{array}{l}\text { Sulfate flux not quantified. } \\
\text { Silica flux: } 10^{12} \text { particles per } \\
\text { second, } \sim 7000 \mathrm{~kg} \mathrm{~d}^{-1} \text {. Total } \\
\text { nanoparticles } \sim 10^{18} \mathrm{~s}^{-1} \text {. }\end{array}$ & $\begin{array}{l}\text { Sulfate }\left(\mathrm{SO}_{4}{ }^{2-}\right) \text { and Sodium } \\
\left(\mathrm{Na}^{+}\right) \text {as main ions, minor ions: } \\
\mathrm{F}^{-}, \mathrm{Cl}^{-}, \mathrm{Ca}^{2+}, \mathrm{K}^{+}, \mathrm{NH}_{4}^{+} \\
\text {Sulfate: } \mathrm{SO}_{2} \text { molar ratios of } \\
0.017-0.05\end{array}$ \\
\hline $\begin{array}{l}\text { Vance et al. } \\
2010\end{array}$ & $\begin{array}{l}\text { In-situ OPC (TSI AeroTrak 8220) } \\
\text { (summit \& near-source plume) } \\
\text { Range: } 0.3 \text { - } 10 \mu \mathrm{m} \text { diameter }\end{array}$ & $\begin{array}{l}\text { Coincidence errors affected measurement, } \\
\text { lower limits reported. } \\
\text { Total surface area: } 4-78 \mathrm{~cm}^{2} \mathrm{~m}^{-3} \\
\text { Number density: } 75-860 \mathrm{~cm}^{-3}\end{array}$ & - & - \\
\hline $\begin{array}{l}\text { Shcherbakov et al., } \\
2016\end{array}$ & $\begin{array}{l}\text { Instrumented Aircraft, plume } \\
\text { transects }>6 \mathrm{~km} \text { downwind. Polar } \\
\text { Nephelometer, Forward Scattering } \\
\text { Spectrometer probes }\end{array}$ & $\begin{array}{l}\text { Number size distributions with effective } \\
\text { radius } 0.7-1.4 \mu \mathrm{m} \\
\text { Differences in BN/NEC optical properties }\end{array}$ & - & $\begin{array}{l}\text { Porous with air voids } \\
\text { (estimated at } 18-35 \% \text { ) }\end{array}$ \\
\hline $\begin{array}{l}\text { Roberts et al., } \\
\text { This study }\end{array}$ & $\begin{array}{l}\text { In-situ OPC (LOAC: } 0.1 \mathrm{~Hz} \text { data) } \\
\text { (summit \& near-source plume) } \\
\text { Range: } 0.2 \text { - } 50 \mu \text { m diameter } \\
\text { Multi-Gas co-measured in-situ } \mathrm{SO}_{2} \\
\mathrm{SO}_{2} \text { flux from DOAS-FLAME network }\end{array}$ & $\begin{array}{l}\text { Particle volume well-correlated to } \mathrm{SO}_{2} \text {. } \\
\text { Coincidence errors traced. Tri-modal } \\
\text { distribution exhibits volume maximum ( 1-2 } \\
\mu \mathrm{m} \text { ) within measurement range, area } \\
\text { maximum at/beyond lower size-limit. }\end{array}$ & $\begin{array}{l}0.7 \mathrm{~kg} \mathrm{~s}^{-1} \text { mass flux at measured } \mathrm{RH} \\
(40 \%) \text { and } \mathrm{T}(285 \mathrm{~K}) \text {, calculated } \\
\text { using assumed } \mathrm{H}_{2} \mathrm{SO}_{4(\mathrm{aq})} \text { or } \\
\mathrm{NaHSO}_{4(\mathrm{aq})} \text { composition. } \\
10^{16} \mathrm{~s}^{-1} \text { number flux (lower limit) }\end{array}$ & $\begin{array}{l}\text { No direct measurements. } \\
\text { Analysis of volume: } \mathrm{SO}_{2} \\
\text { assuming } \mathrm{H}_{2} \mathrm{SO}_{4(\mathrm{aq})} / \mathrm{NaHSO}_{4(\mathrm{aq})} \\
\text { composition, yields estimated } \\
\text { sulfate: } \mathrm{SO}_{2} \text { of } 1-2 \%\end{array}$ \\
\hline
\end{tabular}


Table 3. Physical parameters measured during field campaign and calculated $\mathrm{H}_{2} \mathrm{SO}_{4(\mathrm{aq})}$ and $\mathrm{NaHSO}_{4(\mathrm{aq})}$ properties.. The molar volume of $\mathrm{H}_{2} \mathrm{SO}_{4(\mathrm{aq})}$ is calculated at the observed temperature and Relative Humidity using parameterisations from Tabazadeh et al. (1997) for wt\% $\mathrm{H} 2 \mathrm{SO} 4_{(\mathrm{aq})}$ and density. The molar volume of $\mathrm{NaHSO}_{4(\mathrm{aq})}$ is calculated at the observed Relative Humidity using parameterisations from Tang and Munkelwitz (1994) for wt\%NaHSO4${ }_{(a q)}$ and density. See Appendix A1 for details.

\begin{tabular}{|c|c|c|c|c|}
\hline Parameter & DW1 & DW2 & Flank & Vweak \\
\hline Atmospheric density (molec. $\mathrm{cm}^{-3}$ ) & $1.84 \times 10^{19}$ & $1.84 \times 10^{19}$ & $1.76 \times 10^{19}$ & $1.83 \times 10^{19}$ \\
\hline Temperature $\left({ }^{\circ} \mathrm{C}\right)$ & 15.4 & $15.4^{*}$ & 10.5 & $11.9 *$ \\
\hline Relative Humidity (\%) & 49 & $49 *$ & 21 & $38 *$ \\
\hline $\mathrm{Wt} \% \mathrm{H}_{2} \mathrm{SO}_{4}(\%)$ at $\mathrm{RH}$ and $\mathrm{T}$ & 42 & 42 & 56 & 48 \\
\hline Density $\mathrm{H}_{2} \mathrm{SO}_{4(\mathrm{aq})}\left(\mathrm{g} \cdot \mathrm{cm}^{-3}\right)$ at RH and T & 1.33 & 1.33 & 1.47 & 1.39 \\
\hline Molar volume $\left(\mathrm{cm}^{3} \cdot \mathrm{mol}^{-1}\right)$ at $\mathrm{RH}$ and $\mathrm{T}$ & 175 & 175 & 119 & 147 \\
\hline Wt\% $\mathrm{NaHSO}_{4}(\%)$ at $\mathrm{RH}$ and $\mathrm{T}$ & 67 & 67 & 85 & 75 \\
\hline Density $\mathrm{NaHSO}_{4(\mathrm{aq})}\left(\mathrm{g} \cdot \mathrm{cm}^{-3}\right)$ at RH and T & 1.68 & 1.68 & 1.96 & 1.79 \\
\hline Molar volume $\left(\mathrm{cm}^{3} \cdot \mathrm{mol}^{-1}\right)$ at $\mathrm{RH}$ and $\mathrm{T}$ & 107 & 107 & 72 & 89 \\
\hline
\end{tabular}

*indicates humidity data measured shortly before selected time-period

Table 4. Molar $\mathrm{SO}_{4}{ }^{2-}: \mathrm{SO}_{2}$ ratios estimated from measured total particle volume and $\mathrm{SO}_{2}$ time-series, assuming $\mathrm{H}_{2} \mathrm{SO}_{4(\text { aq) }}$ or $\mathrm{NaHSO}_{4(\text { aq) }}$ composition, and molar volume (Table 3). Two sets of calculations are made, using the gradient of Figure 6 (direct analysis of Vweak plume measurements) or the lognormal distribution fitted to selected data optimised to minimise coincidence errors (see Table 5).

\begin{tabular}{|c|c|c|}
\hline Parameter & $\begin{array}{c}\text { Directly } \\
\text { analysed } \\
\text { Vweak }\end{array}$ & $\begin{array}{c}\text { Lognormal } \\
\text { Distribution } \\
\text { (selected data) }\end{array}$ \\
\hline Volume per ppmv $\mathrm{SO}_{2}\left(\mu \mathrm{m}^{3} \cdot \mathrm{cm}^{-3} \cdot \mathrm{ppmv}^{-1}\right)$ & 65 & 43 \\
\hline Atmospheric Density (molec. $\mathrm{cm}^{-3}$ ) & $1.83 \mathrm{E} 19$ & $1.83 \mathrm{E} 19$ \\
\hline Volume per molecule $\mathrm{SO}_{2}\left(\mu \mathrm{m}^{3} \cdot \mathrm{molec}^{-1}\right)$ & 3.5E-12 & 2.3E-12 \\
\hline Volume per mole $\mathrm{SO}_{2}\left(\mathrm{~cm}^{3} \cdot \mathrm{mol}^{-1}\right)$ & 2.11 & 1.39 \\
\hline Molar volume of $\mathrm{H}_{2} \mathrm{SO}_{4(\mathrm{aq})}\left(\mathrm{cm}^{3} \mathrm{~mol}^{-1}\right)$ & 147 & 147 \\
\hline Molar volume of $\mathrm{NaHSO}_{4(\mathrm{aq})}\left(\mathrm{cm}^{3} \mathrm{~mol}^{-1}\right)$ & 89 & 89 \\
\hline $\mathrm{SO}_{4}{ }^{2-}: \mathrm{SO}_{2}$ molar ratio $\left(\mathrm{H}_{2} \mathrm{SO}_{4(\mathrm{aq})}\right)$ & 0.015 & 0.0095 \\
\hline $\mathrm{SO}_{4}{ }^{2-}: \mathrm{SO}_{2}$ molar ratio $\left(\mathrm{NaHSO}_{4(\mathrm{aq})}\right)$ & 0.024 & 0.016 \\
\hline
\end{tabular}


Table 5. Fitted tri-modal aerosol size distribution as plotted in Figures 11 and 12. This is optimal aerosol data from Vweak period, selected when $0.3<\mathrm{SO}_{2}<0.4 \mathrm{ppmv}$ and subsequently normalized to $1 \mathrm{ppmv} \mathrm{SO}_{2}$. See text for details. Three parameters $N, D$ and $\sigma_{\mathrm{g}}$ are provided that describe each fitted lognormal mode (see Appendix $A 3$ for details). Volumetic parameter $D_{v}$ is also given in brackets. Further parameters calculated from the lognormal fit include the effective radius, $R_{\text {eff, }}$ the total number, area and volume integrated over the whole size distribution, and the percentage proportions of the individual three modes $(1,2,3)$ to these totals. Aerosol/ $\mathrm{SO}_{2}$ ratios are finally calculated to derive fluxes (Section 3.4).

\begin{tabular}{|c|c|}
\hline Parameter & \\
\hline Volcanic aerosol submicron mode 1: & \\
\hline $\mathrm{N} 1\left(\mathrm{~cm}^{-3}\right)$ & 1266 \\
\hline $\mathrm{D} 1(\mu \mathrm{m})$ & $0.235(0.34)$ \\
\hline$\sigma_{\mathrm{g}} 1$ & 1.42 \\
\hline Volcanic aerosol medium mode 2: & \\
\hline $\mathrm{N} 2\left(\mathrm{~cm}^{-3}\right)$ & 49 \\
\hline $\mathrm{D} 2(\mu \mathrm{m})$ & $0.57(0.66)$ \\
\hline$\sigma_{\mathrm{g}} 2$ & 1.25 \\
\hline Volcanic aerosol supramicron mode 3: & \\
\hline N3 $\left(\mathrm{cm}^{-3}\right)$ & 18.2 \\
\hline D3 $(\mu \mathrm{m})$ & $1.11(1.56)$ \\
\hline$\sigma_{\mathrm{g}} 3$ & 1.4 \\
\hline Calculated parameters from the model fit & \\
\hline Volcanic $R_{\text {eff }} \mu \mathrm{m}$ & 0.30 \\
\hline Total Volcanic Number, $\mathrm{Nt}\left(\mathrm{cm}^{-3}\right)$ & 1333 \\
\hline Total Volcanic Area, At $\left(\mu \mathrm{m}^{2} . \mathrm{cm}^{-3}\right)$ & 423 \\
\hline Total Volcanic Volume, $\mathrm{Vt}\left(\mu \mathrm{m}^{3} . \mathrm{cm}^{-3}\right)$ & 43 \\
\hline Mode $\%$ contribution to number $(1,2,3)$ & $95,4,1$ \\
\hline Mode $\%$ contribution to area $(1,2,3)$ & $66,13,21$ \\
\hline Mode $\%$ contribution to volume $(1,2,3)$ & $35,14,51$ \\
\hline Co-measured in-situ parameters & \\
\hline $\mathrm{SO}_{2}$ (normalized) ppmv & 1 \\
\hline Atmospheric Density (molec. $\mathrm{cm}^{-3}$ ) & $1.83 \times 10^{19}$ \\
\hline $\mathrm{SO}_{2}$ concentration (normalized) $\left(\mathrm{molec}^{-1} \cdot \mathrm{cm}^{-3}\right)$ & $1.83 \times 10^{13}$ \\
\hline Temperature $\left({ }^{\circ} \mathrm{C}\right)$ & 11.9 \\
\hline Relative Humidity (\%) & 38 \\
\hline Calculated Aerosol/ $/ \mathrm{SO}_{2}$ ratios & \\
\hline Number $/ \mathrm{SO}_{2}$ (particles molec $^{-1}$ ) & $7.3 \times 10^{-11}$ \\
\hline Area $/ \mathrm{SO}_{2}\left(\mu \mathrm{m}^{2}\right.$ molec $\left.^{-1}\right)$ & $2.3 \times 10^{-11}$ \\
\hline Volume $/ \mathrm{SO}_{2}\left(\mu \mathrm{m}^{3} \mathrm{molec}^{-1}\right)$ & $2.4 \times 10^{-12}$ \\
\hline $\mathrm{SO}_{2}$ gas flux by remote sensing & \\
\hline Minimum $\left(\mathrm{t} \mathrm{d}^{-1}\right)$ & 1800 \\
\hline Maximum $\left(\mathrm{t} \mathrm{d}^{-1}\right)$ & 2100 \\
\hline Mean $\left(\mathrm{t} \mathrm{d}^{-1}\right)$ & 1950 \\
\hline Mean Aerosol fluxes & \\
\hline Particle Number (lower limit) $\left(\mathrm{s}^{-1}\right)$ & $1.5 \times 10^{16}$ \\
\hline Surface Area $\left(\mu \mathrm{m}^{2} \mathrm{~s}^{-1}\right)$ & $4.9 \times 10^{15}$ \\
\hline Volume $\left(\mu \mathrm{m}^{3} \mathrm{~s}^{-1}\right)$ & $5.0 \times 10^{14}$ \\
\hline
\end{tabular}

